\title{
A STUDY ON THE DEVELOPMENT OF THE SWEAT GLANDS OF THE CATTLE EMBRYOS
}

\author{
KENJIRO YASUDA, TATSUYA KAGA, TAKEICHRO GOTO, \\ TAKA KASHIMURA, HITOSHI FURUSAWA and \\ KAZUYOSHI KOBAYASHI \\ Departmemt of Anatomy, School of Medicine \\ Keio University
}

(Received on November 11, 1957)

\section{INTRODUCTION}

The skin and its appendages have been studied systematically by several authors, especially many investigations have been reported on the integuments of the embryos and of the animals. As for the development of the sweat glands, a great many of the reports have been done on the human embryos and on the animal embryos. Some of the investigators are: Gurlt (1835), Valentin (1835), Wendt (1834), Remak (1855), Kusnetzaff (1867), Greefbery (1873), Fleming (1884), Blaschko (1888), Kölliker (1889), De Meijere (1894), Maurer (1895), Marks (1895), Bonnet (1891), Alzheimer (1888), Benda (1893), Stöhr (1903), Eggeling. (1904), Backmund (1904), Diem (1907), Wimpfheimer (1907), Brinkmann (1909), Hertwig (1910), Pinkus (1910, 1926), Steimer (1926), Heopke (1927), Schiefferdecker (1922), Schaffer (1924), Alverdes (1932), Tawara (1932), Iwata (1933), Nagai (1936), Ueda (1939a, 1941b), Akagi (1939), Mogi (1939), Morioka (1935), Kan (1941), Narita (1954), Osogoe (1951), Morise (1954), Kitano (1931), Ogiwara (1943).

Nevertheless, only four investigators have reported on the structural figures. of the cattle embryos, they are Gurlt (1835), Wimpfheimer (1907), Blenda (1893), and Chodakowski (1871).

Now, we studied the sweat glands of cattle embryos from the point of their development and histogenesis. The materials are obtained a live stock experiment station.

\section{MATERIAL AND METHOD}

The most difficult problem assigned to us was to get fresh material following the months of fetal life. However, this was settled by a live stock experiment station's courtesy and from the Shibaura slaughter house we could obtain a fresh 
embryos taken out from the mother animal immediately after the death of the mother. As will be noticed hereafter, several parts of the fresh embryos were fixed with $80 \%$ alcholic solution sectioned in $5 \mu$. thick paraffin in the usual way, and stained with Hansen's Haematoxylin-Eosin staining.

The eight cattle embryos ageing from the beginning of the third fetal month to the end of the eighth fetal month were used in this study. Six parts of the fetal body were observed; these parts are forehead (the intermediate part between the eyes), breast (the intermediate part between the terminated regions of the right and left forelegs), abdomen (the median part of the terminatic portion of the umbilical cord a little toward the head side, hypogastrium (the median part of the mammary glands a little toward the head side), back (medial part of the full trunk on the back side) and sole (the portions covered with hair in the center of the caudal side around the portion of the hoof). Though we could know the exact kind of the mother cattles, they would be a Japanese species with brown hair.

Classification according to R.B. Maneely

\begin{tabular}{|c|c|c|c|c|c|c|}
\hline $\begin{array}{l}\text { specimens } \\
\text { number }\end{array}$ & $\begin{array}{l}\text { body length } \\
(\mathrm{cm})\end{array}$ & $\begin{array}{c}\text { body weight } \\
\text { (g) }\end{array}$ & $\begin{array}{l}\text { fetal } \\
\text { month }\end{array}$ & authors & $\begin{array}{c}\text { body length } \\
(\mathrm{cm})\end{array}$ & $\begin{array}{c}\text { body weight } \\
(\mathrm{g})\end{array}$ \\
\hline 33 & 11.5 & 60 & $\begin{array}{c}60 \\
68 \\
70 \\
73 \\
78 \\
77-80\end{array}$ & $\begin{array}{l}\text { Winters } \\
\text { Kislovsky } \\
\text { Bergmann } \\
\quad \quad \text { " } \\
\text { Winters } \\
\text { Bergmann } \\
\text { Kislovsky } \\
\text { Bergmann }\end{array}$ & $\begin{array}{r}6.6 \\
\overline{11.2} \\
14.3 \\
9.4 \\
17.0 \\
\overline{13.0}\end{array}$ & $\begin{array}{c}13.78 \\
56.0 \\
34 \\
120 \\
37.25 \\
215 \\
67.0 \\
130\end{array}$ \\
\hline 20 & 22.3 & 343 & $\begin{array}{c}105 \\
" 1 \\
106 \\
110 \\
112\end{array}$ & $\begin{array}{l}\text { Kislovsky } \\
\text { Bergmann } \\
\text { Winters } \\
\text { Bergmann }\end{array}$ & $\begin{array}{l}21.8 \\
21.0 \\
24.0 \\
21.5\end{array}$ & $\begin{array}{l}450 \\
610 \\
440 \\
550 \\
470\end{array}$ \\
\hline 31 & 27.0 & 730 & $\begin{array}{l}116 \\
118 \\
120 \\
120\end{array}$ & $\begin{array}{c}\prime \prime \prime \\
\text { Winters } \\
\text { Kislovsky }\end{array}$ & $\begin{array}{r}27.0 \\
28.0 \\
27.1 \\
\end{array}$ & $\begin{array}{l}870 \\
830 \\
820 \\
645.7\end{array}$ \\
\hline 32 & 43 & 2900 & $\begin{array}{l}160 \\
161 \\
164 \\
169 \\
170\end{array}$ & $\begin{array}{l}\text { Winters } \\
\text { Bergmann } \\
\text { "' } \\
\text { "' } \\
\text { Winters }\end{array}$ & $\begin{array}{l}43.7 \\
47.0 \\
50.0 \\
55.0 \\
48.5\end{array}$ & $\begin{array}{l}3652 \\
3450 \\
5100 \\
6300 \\
7144\end{array}$ \\
\hline 34 & 60.0 & 8450 & 196 & Bergmann & & \\
\hline 39 & 66.1 & 11800 & $\begin{array}{l}198 \\
200\end{array}$ & Winters & $\begin{array}{l}71.0 \\
58.5\end{array}$ & $\begin{array}{l}12200 \\
10433\end{array}$ \\
\hline 37 & 80.2 & 25180 & $\begin{array}{l}218 \\
220 \\
229 \\
230\end{array}$ & $\begin{array}{l}\underset{\prime \prime}{\text { Bergmann }} \\
\text { Winters }\end{array}$ & $\begin{array}{l}81.0 \\
75.0 \\
82.0 \\
73.0\end{array}$ & $\begin{array}{l}18650 \\
19300 \\
22400 \\
18144\end{array}$ \\
\hline
\end{tabular}


D.A. Kislovsky and B.A. Larchin's classification

\begin{tabular}{c|c}
\hline days after the birth & body weight \\
40 & $2.1(\mathrm{~g})$ \\
53 & 9.2 \\
60 & 56.0 \\
78 & 67.0 \\
90 & 161.5 \\
96 & 327.0 \\
105 & 610.0 \\
120 & 645.7 \\
135 & 1228.0 \\
165 & 3700.0 \\
180 & 6700.0 \\
210 & 11400.0 \\
240 & 15200.0 \\
255 & 18200.0 \\
270 & 30000.0 \\
\hline
\end{tabular}

Table of the fetal month described by Sh. Sato

The first fetal month.-At the end" of the month the embryo attains $11-21 \mathrm{~cm}$ in the body length, and its head becomes distinct from the extremities. Amnion shows a thinner follicular shape and the allantoic membrane contains a little water.

The second fetal month.-In the seventh fetal week the udder is given rise to at the end of the month, the body reaches a length of 6 to $7 \mathrm{~cm}$ and gives rise to the scrotum. An oval turbid punctation which grows into the fetal placenta afterwards in the choroides.

The third fetal month.-In the eleventh fetal week the embryo attains a length of $11 \mathrm{~cm}$ and gives rise to the stomach and scrotum. At the end of the three-month-old fetus the body length becomes $11-17 \mathrm{~cm}$ and $750 \mathrm{~g}$ of the liquid of the blastosphere stays. The quantity of amnion water is about the same with that of the blastosphere.

The four-month-old fetus.-At the end of this fetal month the fetus attains a length of $24 \mathrm{~cm}$, weights $900 \mathrm{~g}$ and on the sheath of the umbilical cord grow many short villi. The cranium ossifies.

The fifth fetal month.-At the beginning of this fetal month, on the lips and the upper eyelid cirri spring up and the mammilae are recognizable. In the male cattle embryo the testicles are descending. At the end of this fetal month the embryo attains a length of 35 to $40 \mathrm{~cm}$ and a weight of 2000 to $3000 \mathrm{~g}$.

The sixth fetal month.-In this fetal month the embryo gives rise to a few crinites at the tip of the tail and becomes 48 to $60 \mathrm{~cm}$ in the body length.

The seventh fetal month.-At the end of this fetal month the embryo gives rise to the long hairs at the tip of the tail and also starts hairs at the horn root and at the cornet portions.

The eighth fetal month.-In this fetal month the embryo rises hairs on the back and at the margin of the ears.

The ninth fetal month.-At the beginning of the month hairs cover the full body and at the end of the month the body length attains 80 to $90 \mathrm{~cm}$.

The tenth fetal month.-By the middle of this fetal month the embryo arrives at puberty. 
Table of Sh. Sato's fetal month

\begin{tabular}{c|c||c|c}
\hline \hline fetal month & body length & fetal month & body length \\
\hline 1 & $1.5 \mathrm{~cm}$ & 6 & $6 \times 8=48 \mathrm{~cm}$ \\
2 & $2 \times 4=8$ & 7 & $7 \times 9=63$ \\
3 & $3 \times 5=15$ & 8 & $8 \times 10=80$ \\
4 & $4 \times 6=24$ & 9 & $9 \times 10=90$ \\
5 & $5 \times 7=35$ & 10 & $10 \times 10=100$ \\
\hline
\end{tabular}

except the first, ninth and tenth month

the body length of the fetus is shown in the next formula.

$n \times(n+2), \quad n=$ fetal month

The table representing the fetal months

\begin{tabular}{|c|c|c|c|}
\hline Specimens number & $\begin{array}{l}\text { body length } \\
\text { (cm) }\end{array}$ & $\begin{array}{l}\text { body weight } \\
(\mathrm{g})\end{array}$ & $\begin{array}{l}\text { asumptive fetal } \\
\text { month }\end{array}$ \\
\hline 33 & 11.5 & 60 & beginning of the $3 \mathrm{rd}$ \\
\hline 20 & 22.3 & 343 & middle-end of the fourth \\
\hline 31 & 27.0 & 730 & beginning of the 5 th \\
\hline 32 & 43.0 & 2900 & middle of the 6 th \\
\hline 40 & 50.3 & 5250 & beginning of the 7 th \\
\hline 34 & 60.0 & 8450 & end of the 7 th \\
\hline 39 & 66.1 & 11800 & beginning of the 8 th \\
\hline 37 & 80.2 & 25180 & end of the 8 th \\
\hline
\end{tabular}

body length $=$ Scheitel-Steiss-Länge.

The exact standard inducing the fetal month of the cattle embryos had not been found until Maneely made a summary of various reports. Though Gurlt (1873), Frank (1893), St. Cyrand Violet (1888), Albrecht (1914) and De Bruin (1910) reported about the body length and body weight of the cattle embryos, these reports are of no value to use because conflicting diverse.

In various considerations mentioned above, the body weight of the embryos differ remarkably from each other, as Asdel (1946) and Maneely (1952) asserted that the body weight of the cattle embryos depended on the kind of the mother cattle. Therefore, we determined the fetal month according to the body length of the embryo with due regard to the body weight of the fetus and to. Sato's method.

\section{OBSERVATION}

1. The figures of the cattle embryo which are $22.3 \mathrm{~cm}$ in body length and $348 \mathrm{~g}$ in body weight.

(middle of the fourth fetal month, specimen number 20)

Forehead (Figs. 1, 2) :-The poorly delineated primordia of the sweat glands: are recognizable as cell groups which in a mammellary shape grow from the side: 
of the rudiments of the hair follicles in a stadium "Haarzapfen" into the dermis at an obtuse angle where the hair-rudiments and the dermis cross. The rudiments of the hair on the forehead are more frequently encountered than those on the other parts of the body, but those which accompany the primordial sweat glands are rarely encountered. The best developed primordia of the sweat glands appear as spherical solid cell groups connected with hair rudiments by a somewhat narrow cell-cord, and the length of the primordia is one-fifth of the hair rudiments. Most of the rudiments of the sweat glands are of hill-like-form or mammellary. The longitudinal axis of the cell groups of the primordial sweat glands generally arranges at right angle with the epidermis in any stadiums. It is recognizable, that a hair rudiment gives rise to two or more cell groups of the primordial sweat glands. The cell groups which consist of the rudiments of the sweat glands are composed of the short cuboidal cells, and their nucleus is round or elliptic in shape, being abundant in chromatin. The cells in the central region of the cell groups which consist of the rudiments of the sweat glands are more round in shape than those in the peripheral region. Nucleus of these cells is round and its stainability for hematoxylin is somewhat weaker than that in the cells which are in the peripheral region.

Breast (Fig. 3) :-In the breast part, the primordia of the sweat glands are not yet recognizable. The border line between the epidermis and the dermis is clear, and an area of the basement layer is thick, forming the hair rudiments. The number of the hair rudiments is few and most of them are in the stadium "Haarvorkeim" (Pinkus).

Abdomen (Fig. 4):-The rudiments of the hair in this part are less encountered than those on the forehead and sole but more than those on the breast. The developmental conditions are later than those on the forehead and sole, but better than those on the breast, hypogastrium and back. Namely, they are generally in the stages of "meilerartiger Haarkeim" (Maurer and Nagai) and of "Haarvorkeim" (Pinkus). The primordia of the sweat glands are recognizable at the root of a few hair rudiments. The primordial sweat glands are recognizable as a low hill-like-cell group at the obtuse side, where the hair rudiments, being in the stadium "Haarzapfen" (Stöhr) or "meilerartiger Haarkeim" (Maurer), cross with the epidermis. These cell groups of the primordial sweat glands are more dense in their arrangement than those of the hair rudiments, and moreover the stainability for hematoxylin in these cells is stronger. It is not recognizable that on the mammellary shape the hair rudiment give rise to the primordial sweat glands.

Hypogastrium (Fig. 5):-In this portion the primordia of the sweat glands 
are not yet noticeable. The rudiments of the hair are more perceptible than those of the breast. The development of the hair rudiments falls behind those of the head and sole and is generally in the state of "Haarvorkeim" (Pinkus) and "bogenförmiger Haarkeim" (Stöhr).

Back (Fig. 6) :-In this portion the primordial sweat glands are not yet recognizable. The number and the condition of the development are about similar to those of the hypogastrium but the state of a "bogenförmiger Haarkeim" is longer than that in the hypogastrium.

Sole (Fig. 7):-The hair rudiments are about equal to or somewhat more numerous than those on the forehead and always more numerous than those in the portions of the body except the forehead. The development of the hair rudiments is well and the rudiments develop into the dermis as deep as those of the forehead. The best developed rudiments of the hairs are in the state of "Haarzapfen" (Stöhr). The extent of an obtuse angle, where the hair rudiments cross with the epidermis is smaller as compared with that of the back and hypogastrium and it is nearer to the right angle. The hair rudiments in which the primordia of the sweat glands are recognizable are in the phase or stage of "Haarzapfen" (Stöhr) and their number is as numerous as seen on the forhead. The best developed primordia of the sweat glands are recognizable as the cell groups projecting from the root of the hair rudiments mammellary. But the spherical primordia of the sweat glands which connect with the hair rudiments by a thin cell cord as recognized on the forehead portion are not noticeable. Most preceptible primordia of the sweat glands are those which project from the hair rudiments in hill-like-or mammellary shape. The nucleus of the peripheral portions of the primordial cell groups stains with hematoxylin stronger than that of the cell groups of the hair rudiments. It is not noticeable that one hair rudiment gives rise to two or more primordia of the sweat glands.

From the findings mentioned above, comparing the development of the primordia of the sweat glands with the relation among their number, form and the hair rudiment, the earliest primordia of the sweat glands are recognizable in the portion of the forehead and sole. Compared with the forehead and the sole, the hair rudiments are more numerous in the sole and the primordia of the sweat glands are about equal to one another or somewhat more in the sole, but the best developed primordia of the sweat glands (which is spherical shape) are recognizable only on the forehead. Next to the forehead and sole, in the abdomen a few primordia of the sweat glands which are in a very early phase are noticeable. The primordia of the sweat glands recognized in the abdominal portion are considered to be the earliest developed primordia; the developmental 
stage of the hair rudiments, to which this primordia in the abdomen belongs, is earlier than that of the hair rudiment to which the same developed primordia in the forehead and sole belong. The primordia of the sweat glands in the breast, hypogastrium and back are not yet recognizable but only the hair rudiments in different stages are noticeable. The order of the development of the hair rudiments in three parts as mentioned above, is the back, hypogastrium and breast.

\section{The figures of the cattle embryo which is $27 \mathrm{~cm}$ in the body length and $730 \mathrm{~g}$ in body weight. (Beginning of the fifth fetal month. Specimen number 31)}

Forehead (Fig. 8):-In comparison with the previous specimen, the hair rudiments in this specimen are recognized more numerously. The best developed rudiments of the hair are in the phase of "Haarzapfen" but their length is longer than that in the phase of "Haarzapfen" which is recognized on the forehead and sole in the previous specimen. The number of the primordial sweat glands is less than that of the hair rudiments. The best developed rudiments of the sweat glands are a clavate shaped primordia which is about the same length as "Haarzapfen." Namely, the primordia of the sweat glands grow from the root of the hair rudiments into the dermis as a slender cell cord, descending parallel with the hair rudiments, forming a clavate shape according to the expansion at the end of the primordia. Most recognized primordia of the sweat glands are a spheric form which connects with the hair rudiments by a short cell cord. A few mammelary shaped primordia are noticeable. The primordia of the sweat glands come out at the root of the hair rudiments from the obtuse angle where the hair rudiments cross with the epidermis. However, some of the primordia of the sweat glands come out from the transitional part between the hair rudiments and the epidermis. Generally the cells which compose the primordia of the sweat glands are of a short columnar form and the cytoplasm has a stronger stainability to eosin staining than that of the hair rudiments. The nucleus is round or elliptic but that of the cell cord of the primordia at its central region is round. In the clavate shaped primordia of the sweat glands, two cell cords, one of which connects with the ampulla and another connects the ampulla with the hair rudiments, are recognizable. The ampulla consists of the round cell groups and the boundary between the cells is clearly not noticeable. The nucleus is round and is abundant in chromatin. The cell cord is composed of the cells which line up two or three rows. And the outer cells of the cord are flat and their nucleus is flat elliptic or spindle shaped, being abundant in chromatin, on the other hand 
the inner cells are round having the round nucleus which is scarce of chromatin.

Breast (Fig.9) :-The number of the hair rudiments is fewer than that on the forehead. The best developed hair rudiments are in the stadium of "Haarzapfen." In comparison with the primordia of the sweat glands on the forehead, the primordia in this portion are fewer in their number and are later in their development, that is, no primordia develops so well as the mammellary one. Most of the primordia of the sweat glands are shaped hill-like. The primordia of the sweat glands were not recognizable on the breast in the previous period but in this period the primordia are recognizable. These primordia are noticed as the cell groups of the vast basement at the obtuse angle side where the rudiments cross with the epidermis at the root of the hair rudiments which are in the stadium of "Haarzapfen," as recognized on the other parts of the body. One rudiment of the hair does not give rise to two or more primordia of the sweat glands and moreover it is not recognizable that the primordia arise from the acute angle side where the hair rudiments cross with the epidermis, and that the primordia of the sweat glands originate directly from the epidermis. The figures of the tissues of the hill-shaped and mammellary primordial sweat glands are about similar to those of the forehead, sole and abdomen in the previous pericd.

Abdomen (Fig. 10):-The number of the hair rudiments is less than that on the forehead and is about the same as that on the breast. But the length of the hair rudiments is longer than that on the breast in the same stadium of "Haarzapfen." The primordia of the sweat glands on the abdomen are fewer in number than that on the forehead and are about of the same distribution as that on the breast. As for the best developed primordia of the sweat glands, it is recognized that the primordia show the form which the mammellary ones attain to the spheric ones being about to apart from the hair rudiments. Most of the primordial sweat glands are of the mammellary form. The primordia of the sweat glands whose form is hill-shaped and the hair rudiments which do not give rise to the primordia of the sweat glands are recognizable. The boundary areas between the area of the primordia of the sweat glands originate from the part where the hair rudiments transit to the epidermis and the area where the hair rudiments transit to the epidermis, and between the former and the area where the primordia of the sweat glands transit to the hair rudiments are obscure.

Hypogastrium (Fig. 11):-The number of the hair rudiments is less than that on the forehead but is about equal to those on the breast and abdomen. The best developed hair rudiments are in the stadium of the "Haarzapfen." The number of the primordia of the sweat glands is less as compared with that of 
the hair rudiments. Many hair rudiments, which do not give rise to the primordia of the sweat glands are recognizable. The best developed primordia of the sweat glands show the hill-shaped cell groups. Between the cells of the primordial sweat glands and the cells corresponding with the external root sheath of the hair rudiments, no differences exist in their stainability.

Back (Fig. 12) :-The number of the hair rudiments on this part of the body is about the same as that on the hypogastrium. The best developed hair rudiments are in the stadium of "Haarzapfen." It is seldom that the hair rudiments originate the primordia of the sweat glands. In the best advanced stadium the primordia of the sweat glands exhibit the mammellary ones. Moreover, the hill-shaped primordia of the sweat glands are frequently perceptible. In the mammellary primordia of the sweat glands, the nuclei at their tip have a strong stainability for hematoxylin and their chromatin show a close net-work and at the knotted point of the coarse net-work the mass of chromatin is discernible. Sometimes the figure considered to be a mitosis is recognizable. It is seldom noticed that the primordia of the sweat glands arise from the region where the hair rudiments transit to the epidermis.

Sole (Fig. 13) :-The number of the hair rudiments is as numerous as that on the forehead. The length of the hair rudiment is also as long as that on the forehead. The number of the primordia of the sweat glands is the most numerous all the other parts of the body. The best developed primordia of the sweat glands show a clavate form and have a cell-cord which descends as far as half of the hair rudiments. The tip of cord is inflated a little. The cell-cord of the hair rudiment above the inserted portion of the primordia of the sweat glands is broad, and it frequently joins the epidermis. The dermal layer around the tip of such a long primordia of the sweat glands is perceptible as a Iumen which in sections does not stain with eosin. The primordial cells of the sweat glands are composed of three or four lines of the cells and their nucleus is generally bigger than that of the hair-rudiments, being abundant with chromatin which is a big knot-like mass. Sometimes the nucleus is one and half to twice as big in diameter as that of the usual primordia of the sweat glands. Such a big nucleus is generally noticed at the region between the center and the tip of the cell-cord of the primordial sweat glands. Ordinarily one cell layer of the most external layer of the primordial sweat glands is stronger in stainability to hematoxylin than that of the internal layer. The cytoplasm of the primordia of the sweat glands stains with eosin more intensive as compared with that of the hair rudiments. The most discernible primordia of the sweat glands on the sole is a spherical one which connects with the 
hair rudiment by a short cell-cord and a short clavate one.

From the observations mentioned above, in the embryo which is $27 \mathrm{~cm}$ in body length and $730 \mathrm{~g}$ in body weight, the earliest developed part of the primordia of the sweat glands are the forehead and sole. Compared with the forehead and the sole, the part, where the primordial sweat glands in the well developed stadium are numerous in their number, is the sole, while on the forehead the best developed primordia of the sweat glands are perceptible. Next in line to both parts are the abdomen, back, hypogastrium and breast where the developed primordia of the sweat glands is recognizable. It is not yet found that the primordia of the sweat glands differentiates with the excretory duct and the glandular corpus and that a bending at the tip occurs and that the internal cavity is found in the glandular corpus and that the myoepithelial cell differentiates. Besides, on the primordia of the sweat glands the proper membrane, melanophoren and pigmental granules are not noticed at all.

\section{The figures of the embryo which is $43 \mathrm{~cm}$ in body length and $2900 \mathrm{~g}$ in body weight. \\ (Middle of the sixth fetal month, Specimen number 32)}

Forehead (Fig. 14):-The primordia of the hair follicles grow deeply into the dermis. Though the best developed hair rudiments are in the stadium of the "Bulbuszapfen" (Stöhr), most of them are in the stadium of the "Haarzapfen." It is rarely that the hair rudiments are in the stadiums of the "Haarvorkeim" (Pinkus), "bogenförmiger Haarkeim" (Söhr) and "Meilerartiger Haarkeim" (Maurer). The primordia of the sweat glands descend along the rudiments of the hairs at a right angle with the epidermis, reaching to the hair bulbs or as deep as the basal portion of the hair papilla. The apex of the primordia of the sweat glands is inflated and its inflated portion of some primordia bend like a hook. Namely, in this period the best developed primordia of the sweat glands are the hook-shaped or clavate ones. Sometimes the spherical primordia of the sweat glands are perceptible but the papillar primordia are not recognizable. Most of the hook shaped primordia are recognized in the primordial sweat glands which belongs to the hair rudiments in the stadium of the "Bulbuszapfen" and among them the formation of the glandular lumen which is narrow cleft-like one, is found. Moreover, the primordia of the sweat glands in which the glandular lumen broaden and consist of two or three layers of flat cells, are found. It is in this period that the formation of the glandular lumen to become the secretary region is found for the first time. At first 
the formation of the glandular lumen begins at the upper part of the center of the apical ampulla of the primordial sweat glands that is, at the part where the apical ampulla transits to the cell cord which connects with the hair rudiment. On the primordial of the sweat glands in which a considerable broad glandular lumen was formed, in the utmost apical region of the ampulla the cell groups forming two or three layers are recognizable, and in the transitional region to the cell cord the glandular lumen is surrounded with one or two cell layers and more in the region near the epidermis the glandular lumen is not found at all, showing none the luminal cell cord gradually. It is recognizable from these facts that in order of the transitional region, region of glandular corpus and excretory region, the glandular lumen shows the figure of its formation.

On the clavate primordia of the sweat glands the nucleus in the cells of the ampulla of the apex of the primordia and the nucleus in the cells which locate as high as one and half of the ampulla of the cell cord connecting with the ampulla and the hair base have a stronger stainability for hematoxylin than those of the hair bulb of the hair base, those of the papillar primordia and those of the cells locating in the dermis, as well as those of the hair bulb and hair papillar base. On the primordia of the sweat glands which bend like a hook, almost the same figures as those on the clavate primordial sweat gland are recognizable. On the primordia of the sweat glands in which the formation of the lumen is recognizable, the nucleus in the cells of the transitional region to the cell cord connecting with the ampulla of the apex of the primordia and the hair base has an intensive stainability for hematoxylin.. Generally the cytoplasm in the apical ampulla of the primordia of the sweat glands stains more intensive with eosin than that of the hair base. The cell cord which connects with the ampulla and the hair base consists of two or three cell layers. The outer cells of the cell cord have a stronger stainability for eosin than the inner cells. In the cell cords and in a part of the apical ampulla of the primordial sweat glands themselves and in their peripheral regions the flat cells which contain a flat or spindle shaped nucleus are recognizable. In case of these cells arranging themselves along the longitudinal axis of the primordia of the sweat gland, they may not differentiate from the external cells of the primordia of the sweat glands. In such a case, where the nucleus of these cells in the dermis is flatter than that of the external cells in the primordia of the sweat glands and where these cells do not arrange themselves parallel to the longitudinal axis of the primordial sweat glands, but each of the cells arranges its own direction, these cells are distinguished from the 
external cells of the epithelial primordia of the sweat gland. The inserted region of the primordial sweat glands to the hair base is generally the transitional region between the hair base and the epidermis. It is rare that the inserted region of the sweat glands to the hair base is two-fifth to one-third on the hair base as recognized in the papillar and spherical primordia. Though a hair base does not give rise to two or more primordia of the sweat glands, each of all the hair bases always has a primordia of the sweat glands in this period.

Breast (Fig. 15) :-The primordia of the sweat glands insert deeply into the dermis, and most of them are in the stadium of "Haarzapfen." The primordia of the sweat glands descend along the "Haarzapfen" to the dermis at a right angle with the epidermis, and attain the part which is two-thirds to three-fourths of the length of the hair base. The primordia of the sweat glands in the best developed stadium are the clavate ones. Besides, the primordia, which are generally recognizable are too the clavate ones. The number of the primordia of the sweat glands is more numerous than that of the corresponding part of the body in the previous period. Each of the hair bases always gives rise to a primordia of the sweat glands. Though some primordia of the sweat glands which form a spherical shape are recognizable, it is not recognized that figure of the papillar primordia of the sweat gland appeared in this period. Also as recognized on the forehead, the primordia of the sweat glands, which bend like a hook are not perceptible. In the transitional part between the primordia of the sweat glands and the cell cord, which connects with the hair base and the ampulla of the apex of the primordial sweat glands, the arrangement of the cells is occasionally loose, but no primordia of the sweat glands in which the formation of the glandular lumen is clearly seen are perceptible.

. Abdomem (Fig. 16):-Most of the hair bases are in the stadium of "Haarzapfen." The primordia of the sweat glands are more numerous as compared with those on the same part of the body in the previous period. The best developed primordia of the sweat glands are the clavate one. The most recognized primordia are perceptible as only a rod-like cell cord which is one and half of the hair base in length and keeps the same thickness over its full cord. A few primordia of the sweat glands where the apical point of the rod-like cell cord is turgid a little also come in view. The primordia of the sweat glands which bend like a hook and which have an excretory tubular lumen are not yet recognized. The length of the best developed clavate primordia of the sweat glands is generally one and half to one-third of that 
of the hair bases. Their development is later than in this part of the body as compared with that on the forehead, breast, back and sole.

Hypogastrium (Fig. 17):-The best developed hair bases are in the stadium of "Bulbuszapfen" but most of them are in the stadium of "Haarzapfen." The number of the primordia of the sweat glands increase more than those on the same part of the body in the previous period. The best developed primordia of the sweat glands are the clavate ones. A few primordia of the sweat glands which bend a little like a hook at the apical ampulla of the primordia are perceptible. On the hypogastrium in this period, a great difference exists between the best developed primordia of the sweat glands and the worst developed one. Generally the hair bases on this part of the body are short as compared with those on the other parts of the body and the primordia of the sweat glands is also shorter. The formation of the glandular lumen is not yet found, but the primordia of the sweat gland, in which somewhat loosely arranged cells in the transitional region between the apical ampulla of the primordia and the cell cord are noticed, are found a few. On the rod-like and the clavate primordia of the sweat glands the nucleus which sits on the part from the primordial apex to a half of the cell cord in the height, has an. intensive stainability for hematoxylin.

Back (Fig. 18):-The best developed primordia of the sweat glands are in the stadium of "Bulbuszapfen." But most of the primordia of the sweat glands are in the stadium of "Haarzapfen." The primordial sweat glands are of about the same length as the hair base reaching deeply into the dermis. The best developed primordia of the sweat glands bend like a hook at the apex of the primordia, but are not yet clear in the formation of the glandular lumen. Sometimes the figures which suggest the formation of the glandular lumen because being of loose arrangement of the cells, which are located at the transitional region between the ampulla of the primordia and the cell cord, are traceable. The rod-like and clavate primordia are recognizable most numerously. No spherical and papillar primordia of the sweat glands are perceptible.

Sole (Fig. 19, 20):-The primordia of the hairs are almost in the stadium of "Haarzapfen." The rudiments of the sweat glands are generally two-third of the hair primordia in length, or the same as the hair bases. But the clavate primordia are short as compared with that of other parts of the body (Fig. 18). The best developed rudiments of the sweat glands bend like a hook (Fig. 19). The most recognizable bases of the sweat glands are the clavate ones (Fig. 18). The worst developed bases are the rod-like ones. 
As a whole, the nucleus at the apical ampulla of the primordia of the sweat glands has an intensive stainability for hematoxylin. The inner constraction of the nucleus is not clear. At the region of the ampulla a big nucleus, which is two or three times as large as the ordinary one is often perceptible. The cell cord consists of several arrangements of cells and its nucleus shows a strong stainalility, as well as that at the ampulla. The cytoplasms of the cells which are located at the ampulla and cell cord have a stronger stainability for eosin than that of the hair bases.

From the observations mentioned above, on the cattle embryo, which is $43 \mathrm{~cm}$ in body length and $2900 \mathrm{~g}$ in body weight, the region in which the development is earliest and the formation of the glandular lumen is recognizable, is the forehead. Secondly, on the hook like primordia, the regions in which some signs of appearance of the glandular lumen are noticed though they are obscure, are the breast, back, hypogastrium and the abdomen at the last. On the sole the formation of the glandular lumen is not yet observable. Compared with the developmental order of the primordia of the sweat glands in this period and that in the previous period-that is at first the forehead, next sole, abdomen, back, hypogastrium and breast at the last-, on the forehead both the appearance and development of the primordia of the sweat glands are earliest, but on the sole the appearance of the primordia of the sweat glands is earlier while its development is latest of all the part of the body. Though on the breast the appearance of the primordia of the sweat glands is latest, the developmental rate is as high as next to that on the forehead. In consideration of these facts, with the findings on the abdomen, hypogastrium and back, the order of appearance of the primordial sweat glands does not always go parallel with the developmental rate of the primordia. Rather, with the exception of the forehead the reverse relationship is indicated. It is the specific figures in this period, that at the apical ampulla of the primordia of the sweat glands the bending portion appears, and that on some parts of the body the formation of the glandular lumen is recognizable. The differentiation of the myoepithelial cells and of the proper membrane is not yet clearly observable. A hair base always gives rise to a primordia of the sweat glands but the former does not give rise to two or more of the latter. The region of the insertion of the primordial sweat glands in the hair bases is the transitional area between the hair base and the epidermis in almost cases. The primordia of the sebaceous glands are recognizable on the hypogastrium and sole in this period. These two regions common to such a figure as the lower developmental rate of the primordial sweat glands. This suggests that 
some causal relations exist between the appearance of the sebaceous glands and the development of the primordial. sweat glands.

\section{The figures of the cattle embryo which is $50.3 \mathrm{~cm}$ in body length and $5250 \mathrm{~g}$ in the body weight. (Beginning of the seventh fetal month, specimen number 40)}

Forehead (Fig. 21):-Though the hair bases in the best developed stage show a figure of "Scheidenhaare," most of them are in the stage of "Bulbuszapfen" (Fig. 20). The primordia of the sweat glands deeply invade the dermis, as far as or more deeply than the hair bulbs. Many apical ampullae which bend toward the side of the hair bases or bend like a hook surrounding the hair bulb, are recognizable. On the best developed primordia of the sweat glands a considerably broad glandular lumen is perceptible at the ampulla of the apex, where the primordia bend like a hook. Namely, on the upper part of the apical ampulla, which bends like a hook, near the transitional region between the apical ampulla and the cell cord, the formation of the glandular lumen is noticeable; sometimes the apical ampulla of the primordia is surrounded with a layer of the epithelial cells and with the flat cells which arrange themselves irregular. While on the cell cord, two layers of the cells, one of them is the inner layer, consisting of short cuboidal cells and the other, the outer layer, consisting of the flat cells, are recognizable (Fig. 20). The glandular epithelial cells are flat and short cuboidal and the nucleus is elliptic, locating on the center of the cell. The cytoplasm stains deeply with eosin. The boundary lines between the cells are obscure. The nucleus of the epithelial cells has more intensive stainability for hematoxylin than that of the cell cord. Inside the glandular lumen the cells which have a weak staining nucleus are perceptible. (Fig. 20). The cell cord consists of two or three rows of the cells and it is slender. Besides, it describes an arc along the hair base at its half-way, bending a little at one or two points of the way. Hereafter, the cell cord ascends along the margin of an obtuse angle side of the primordia of the sebaceous glands which is recognized at the base of the hair rudiments continuing the epidermal cells near the transitional region between the hair base and the epidermis. In addition to these observations the primordia of the sebaceous glands and "Haarwulst" are perceptible in the forehead.

Breast (Fig. 22) :-Most of the hair bases are in the stage of "Bulbuszapfen." The primordia of sweat glands are generally two-thirds of the same length as the hair bases. The best developed primordia of the sweat glands have a broad glandular lumen at their apical ampulla. The primordia showing 
174 K. Yasuda, T. Kaga, T. Goto, T. Kashimura, H. Furusawa \& K. Kobayashi

a curve like a hook and a clavate form are recognized to be numerous. These various primordia of the sweat glands are of about the same findings in each period mentioned above, but they are generally shorter in length than those of the forehead. The cell cord which is expected to become the excretory duct later on rarely shows a slight bending as seen on the forehead, while the cell cord on the breast bends describing a large arc along the obtuse angle section where the hair bases cross the epidermis and transit the apical ampulla of the primordia just above the hair bulb. Some of the cell cords connect with the cell groups of the hair bases at one-third of the part above "Bulbuszapfen." Just under the epidermis the cells of the cell cord and the cells of the hair bases are not distinguishable. These cases are recognizable in the hair bases where the primordial sebaceous glands are not perceptible (Fig. 22).

Abdomen (Fig. 23): - The hair bases are almost in the stage of "Bulbuszapfen" and they are shorter than those on the forehead. The primordia of the sweat glands grow as long as or about two-thirds of the hair base but their full length is shorter than that on the forehead. On the best developed primordia of the sweat glands, the arrangement of the cells inside the primordia becomes out of order, from the apical ampulla to the cell cord, which is to grow into the excretory duct later on, and shows an earlier figure of the formation of the glandular lumen. The primordia which have a glandular lumen surrounded with a clear epithelial cell layer are not yet found. At the transitional region between the ampulla and the cell cord, a cleft-like lumen is noticeable and the nucleus of the cells which surround the lumen has a weak stainability for hematoxylin. There are few primordia which have not yet a glandular lumen. The most recognizable primordia of the sweat glands are the clavate ones and there are many primordia which grow as long as the upper part of the hair bulb. On the hook-like primordia and on the anlagen where a sign of the formation of the glandular lumen is recognized, the cell cord ascends along the obtuse angle side of the hair base and bends along the margin of the sebaceous glands, then gradually the course of the cell cord becomes obscure, running into the cell layer of the epithelium. On the other hand, on the clavate primordia the cell cord ascends vertically along the hair base, decreasing its thickness from the ampulla which locates on the upper region of the hair bulb and transits to the cell groups of the hair base at the region where the hair base inserts the epidermis.

Hypogastrium (Fig. 24):-Most of the hair bases are in the stage of "Bulbszapfen." The primordia of the sweat glands attain about the same length 
as the hair base, but the clavate primordia end at the upper part of the hair bulb. The best developed bases of the sweat glands show a large glandular lumen, which is surrounded by a layer of the epithelial cells at the apical ampulla. The most recognizable primordia of the sweat glands bend like a hook at the apical ampulla where an earlier figure of the formation of the glandular lumen is perceptible in fissure shape. Also many clavate primordia are found. The cell cord which grows into the excretory duct later on, shows on the hook-like and the clavate primordia the same figures as that on the abdomen. On the other hand, on the primordia where the formation of the glandular lumen is recognized, the cell cord ascends along the hair bases, curves or bends along the lower margin of the sebaceous gland and transits to the cells of the epidermis running parallel with the free surface of the epidermis. On the primordia of the sweat glands, where the glandular lumen was formed, the glandular epithelial cells are very flat and the cytoplasm staing stronger with eosin than that of the cells of the hair bases. Sometimes cells where the cytoplasm is not perceptible are found. The nucleus is elliptic transversally or spheric and has a strong stainability for hematoxylin as compared with that of other kinds of the cells, but here the figure of the mitosis is not noticeable. Around the external margin of the glandular epithelial cells a few cells, which have a flat or spindle-shaped nucleus arrange themselves along the longitudinal axis of the primordia of the sweat glands. These few cells are considered to be myoepithelial cells not yet differentiated. However, based on mere form it is difficult to distinguish them from the connective tissue-cells. Inside the glandular lumen no assumptive secretions are found, but the cells whose nucleus has a weak stainability are found. On the primordia of the sweat glands where the glandular lumen is formed, the cell cord consists of two rows of cells, the inner one of which consists of the short columnar cells, where the nucleus is round, locating on the center of the cytoplasm, and staining deeply and long with easin at the free end which face the lumen of the cytoplasm. The cells of the other row, the outer, which have an elliptic nucleus, are flat. The sebaceous gland at the root of the hair base to which the primordia of the sweat glands conforming a glandular lumen belong, is larger and more developed than that recognized at the root of the hair bases to which the clavate and hook-like primordia belong.

Back (Fig. 25):-Most of the hair bases are in the stage of the "Bulbuszapfen." The primordia of the sweat glands are of about the same length as the hair bases, or sometimes the former is longer than the latter. On the best developed primordia of the sweat glands, the glandular lumen which is 
surrounded with an epithelial cell layer is recognizable at the ampulla of the apex of the primordia. Such primordia are not numerous. The most perceptible primordia of the sweat glands are the hook-like and the clavate ones. These primordia are similar to the findings mentioned before. The number of the hair bases is more numerous than that on the other parts of the body in the same period. Corresponding to this, the number of the primordia of the sweat glands is more numerous. In comparison with the other parts of the body, this part of the body, the back, has the earlier developed sebaceous glands and they occupy the area which is one-third to one-fourth of the hair bases on the epidermic side, sometimes they divide into two lobules surrounding the hair base. The cell cord connects with the apical ampulla of the primordia of the sweat glands, ascending along the hair base and transists to the epidermis at the root of the hair base with the sebaceous glands running along the external round of the cell group of the sebaceous gland or running through the intermediate part of two lobules. A considerable parallelism is recognizable between the development in the sebaceous gland and that in the primordia of the sweat glands which belong to a hair base on the back.

Sole (Fig. 26) :-Most of hair bases are in the stage of "Bulbuszapfen." Comparing with the other parts of the body, in this part the primordia of the sweat glands are thinner and longer and grow into the dermis. Because of the long hair bases as compared with the other parts of the body, the bases of the sweat glands are almost as long as the upper part of the hair bulbs. The best developed primordia of the sweat glands are the clavate ones but not recognizable as a hook-like one or the primordia which have a formation of the glandular lumen as noticed in the other parts of the body. The most perceptible primordia of the sweat glands are the clavate ones. $A_{s}$ in the back, the sebaceous glands are well developed and divide into two lobules.

From the facts mentioned already, in the cattle embryo which is $50.3 \mathrm{~cm}$ in body length and $5250 \mathrm{~g}$ in body weight, the order of the early developed primordia of the sweat glands is the hypogastrium, back, abdomen, breast, forehead and sole. On the sole no primordia of the sweat glands where the formation of the glandular lumen is perceptible are found. Compared with this order and that of the development of the sweat gland, a reversal figure is recognized. Also, as compared with the other parts of the body on the sole the difference in the development between the earlier developed primordia of the sweat glands and the later developed ones is small. Though the correct measurements of the length of the primordial sweat glands did not take, the lengthes of the primordia on the forehead and sole are longer than those in 
the other parts of the body, on the other hand, on the hypogastrium, breast, abdomen and back the length is comparatively shorter than that on the former two. Though the thickness of the cell-cord varies in its full length, on the abdomen and back it is big and small on the sole. The course of the cell cord runs through the central region of the cell groups of the sebaceous glands on the part, where the development of the sebaceous gland is early and great, that is the back and sole, on the part, where the development of the sebaceous gland is later, it runs along the lower margin of the sebaceous gland.

V. The figures of the cattle embryo which is $60 \mathrm{~cm}$ in body length and $8450 \mathrm{~g}$ in body weight.

(End of the seventh fetal month, specimen number 34)

Forehead (Fig. 27):-The hair bases are almost in the stage of "Scheidenhaare" (Stöhr). But the hair bases in the stage of "Bulbuszapfen" are also recognizable. Most of the primordia of the sweat glands are three-fourths of the hair bases in length. These primordia of the sweat glands form a glandular lumen at the ampulla of the apex of the primordia. Namely, at the glandular corpus, generally a thin lumen, which is surrounded with a layer of flat epithelial cells and show the S shaped or elliptic form, is found. However, some primordia of the sweat glands have not yet the lumen which is surrounded with a clear layer of the epithelial cells, but have the one which is surrounded by several cell layers. No assumptive secretion is recognized in the glandular lumen, but sometimes a great number of the cells which have a weak staining nucleus are found. A few flat cells, which have a flat nucleus are perceptible along the external side of the glandular epithelial cells. At the transitional regions between the glandular corpus and excretory tubule, a somewhat narrowing part of the glandular lumen is found. At this part, the cells consist of one or two, sometimes several layers and there the nucleus has more intensive stainability for hematoxylin, than that of the glandular corpus. The flat cells which are recognizable around the epithelium of the transitional part gradually move into the external cells of the excretory tubule and can not be differentiated from the external cells. The excretory duct is a thin cell cord, which is composed of both, inner and outer layers connecting with the transitional part. The duct ascends parallel to the hair base, bending a little near the sebaceous gland, running through the central region of the cell groups of the sebaceous gland and connecting the hair follicle near the surface of the epidermis. The epithelium of the excretory tubule consists of two cell-layers, one of which is composed of the short columnar cells, which have a round nucleus and the cytoplasm, which 
faces the inner lumen stains deeply with eosin in a line. Another one which is the external layer, has flat cells and a flat nucleus. In this period, the formation of the glandular lumen at the excretory tubule is not yet distinctly recognizable. The formation of the glomerule at the glandular corpus is not found.

Breast (Fig. 28):-Though most of the hair bases are in the stage of "Bulbuszapfen," some of them are in the stage of "Scheidenhaare.". The length of the primordia of the sweat glands is the same or somewhat shorter than that of the hair base. In the best developed primordia of the sweat glands, the formation of the glandular lumen is recognizable in a cleft or an elliptic form, but it is not yet recognizable that the glandular lumen is surrounded with a distinct epithelial cell layer. Most of the primordia of the sweat glands show a hook-like figure or a figure of the formation of the glandular lumen in a cleft type. The construction of each primordial sweat gland is almost similar to that in the previous periods. At the excretory tubule no lumen are found and the course of the tubule is alike to that on the other parts of the body. However, the length of the excretory tubule is shorter than that on the other parts of the body.

Abdamen (Fig. 29):-Nearly most of the hair bases are in the stage of "Bulbuszapfen." The earliest developed primordia of the sweat glands has a glandular lumen which is surrounded with an epithelial cell layer. The most recognized primordia of the sweat glands is the one, in which the glandular lumen is recognizable, but is not yet surrounded with a distinct glandular epithelial cell-layer. And in the lumen a weak staining nucleus is perceptible. The primordia of the sweat glands which is noticeable next, are hook-like ones. At the center of the glandular corpus a glandular lumen appears in cleft form. Generally the glandular lumen is round or elliptic, while, as will be shown in Fig. 28 the $\mathrm{S}$ shaped lumen is also recognized. In Fig. 28, the transitional region between the glandular corpus and the excretory tubular lumen is obviously perceptible. At this region the cells, especially the nucleus of the epithelial cells stains with hematoxylin more intensively than those of the glandular corpus and of the excretory tubular lumen. The running directions of the excretory tubular lumen are similar to those mentioned before, while some of them show a figure, opening the orifice into the hair follicles near the orifice of the follicles of the epidermis. At the excretory tubular lumen, the glandular lumen is vaguely perceptible.

Hypogastrium (Fig. 30):-Most of the hair bases are in the stage of "Bulbuszapfen." The best developed primordia of the sweat glands have a 
glandular lumen which is surrounded with a layer of flat epithelial cells. The primordia of the sweat glands bend like a hook and there at the ampulla a cleft-like glandular lumen is noticed are recognizable very numerously. It is seldom that the primordia of the sweat gland have a glandular lumen which is perfectly surrounded by a layer of the glandular epithelial cells. On the primordia of the sweat glands, where the perfect glandular lumen is noticed, the nucleus arranging itself on the transitional region between the excretory tubule and the glandular corpus, has a stronger stainability for hematoxylin than that on the other parts of the body. Though the excretory tubule consists of three or four lines of the cells on the primordia, where the glandular lumen is found at the glandular corpus, most excretory tubules are composed of two lines of the cells. In this case, the lumen of the excretory tubule is recognizable and the cytoplasm which faces the internal Iumen of the inner layer stains deeply with eosin as compared with other parts of the cytoplasm.

Back (Fig. 31) :-Most of the hair bases are in the stage of "Bulbuszapfen." The primordial sweat glands are about similar to the hair bases in length or they grow as deep as just above the hair bulb. The best developed primordia of the sweat glands is the one in which the glandular lumen is not yet perfectly surrounded by a layer of the glandular epithelial cells. The wall of the lumen is composed of two or three layers of the cells. In the glandular lumen, which shows an irregular form, a few cells in which the nucleus. has a weak stainability are perceptible. The most recognizable bases of the sweat glands are the clavate and the hook-like ones. On these primordia of the sweat glands, the excretory tubule consists of three or four lines of the cells and no formation of the glandular lumen are found.

Sole (Fig. 32) :-Most of the hair base are in the stage of "Bulbuszapfen." The best developed primordia of the sweat glands are the hook-like ones and at the ampulla of the apex, where the primordia bend like a hook, a cleft-like and narrow glandular lumen is noticeable. The most generally recognizable primordia of the sweat glands is the one in which the glandular lumen is not perceptible.

From the findings mentioned above, on the cattle embryo, which is $60.0 \mathrm{~cm}$ in the body length and $8450 \mathrm{~g}$ in the body weight, the order in which the best developed primordia of the sweat glands appear numerously is the forehead, hypogastrium, abdomen, breast, back and sole. On the other hand, the arrangement of the developmental stage in the primordial sweat glands is as follows: the forehead, abdomen, hypogastrium, back, breast and sole. On the sole, the latest developed primordia of the sweat glands out of all parts of the body is recognized. 
180 K. Yasuda, T. Kaga, T. Goto, T. Kashimura, H. Furusawa \& K. Kobayashi

Though the length of the primordia of the sweat glands is capable of measuring only in relation with that of the hair bases, the primordia of the sweat glands which terminate in the upper side of the hair bulbs are perceptible on the forehead, sole and back, while on the other parts of the body the bases of the sweat glands attain to the region as deep as or deeper than the hair bulbs do. The special characters of the primordial sweat glands of the cattle embryo in this period are that of the glandular corpus which has a glandular lumen surrounded by a epithelial layer noticed on the forehead, breast, abdomen and hypogastrium, and that the transitional region between the glandular corpus and the excretory tubule is composed of several cell layers as observed on the forehead, abdomen and hypogastrium especially, and the nucleus on this region has a more intensive stainability than that on the other parts of the primordia of the sweat glands.

On the primordia of the sweat glands which have a glandular lumen surrounded by an epithelial cell layer, the epithelium of the excretory tubule consists of two layers, and the inner one of which is composed of short columnar cells, the external one is composed of flat cells. Thereupon, in this period a morphological differentiation between the glandular corpus and the excretory tubule is generally perceptible except some other parts of the body. A few flat cells which have a flat nucleus and locate on the external side of the glandular corpus of the primordia of the sweat glands, which initiate the formation of the glandular lumen and have a glandular lumen surrounded by an epithelial cell layer, are perceptible. These cells are considered to be undifferentiated myoepithelial cells and in this period these cells are recognizable as the cells showing a proper form, which is differentiated from the cells of the primordial sweat glands.

\section{The findings of the cattle embryo which is $66.1 \mathrm{~cm}$ in body length and $11800 \mathrm{~g}$ in body weight. \\ (Beginning of the eighth fetal month, specimen number 39)}

Forehead (Fig. 33) :-Almost of the primordia of the sweat glands have a glandular lumen, which is surrounded by a layer of flat epithelial cells. Around the external side of the epithelial cells, the cells which have several flat nuclei are recognizable. The glandular corpus is found at the upper side of the hair bulbs. The excretory tubule is composed of two cell-layers and the excretory lumen is clearly noticeable. In the cytoplasm of the part, where it faces the glandular and ductular lumen of the glandular and excretory epithelial cells, the layer which stains deeply with eosin linearly is perceptible. At the region, 
where the glandular corpus transits the excretory portion, there is a region, where the ductular lumen is not recognized or if any, it is a very narrow one. The excretory tubule ascends along the hair, opening its orifice into the hair follicles at one-fourth of the portion of the upper side of the hair, far from the epidermis.

Breast (Fig. 34):-The best developed primordia of the sweat glands forms a glandular lumen, which is surrounded by an epithelial cell layer. The most perceptible primordia of the sweat glands is the hook shaped one and has a lumen, which is surrounded by several cell layers and shows an irregular form. At the external side of the glandular cells the flat cells which have a flat nucleus arrange themselves parallel to the glandular lumen. Out of the glandular lumen, which is not surrounded by an epithelial cell layer, a few cells in which the nucleus has a weak stainability are found. The wall of the excretory tubule which connects with the glandular corpus surrounded by a clear epithelial cell layer, is composed of two cell layers and has the excretory tubular lumen. On the other hand, the wall of the excretory tubule, which connects with the glandular corpus, having a cleft-like glandular lumen is not yet composed of the two clear layers and the excretory tubular lumen is also not distinct. The excretory tubule ascends along the hair and opens its orifice into the hair follicle near one-fourth of the region above the hair. At the transitional region between the glandular corpus and the excretory tubule, a narrow portion which is surrounded by several cell layers is recognizable.

Abdomen (Fig. 35):-The primordia of the sweat galnds grow in the region as deep as the hair bulbs do. The best developed primordia of the sweat glands have a glandular lumen, which is surrounded by a layer of short cuboidal epithelial cells. The most recognizable primordial sweat glands are the ones which form a bending like a hook and also the primordia which have a narrow cleft-like glandular lumen. As for the latest developed primordia of the sweat glands, the clavate primordia is recognized. The formation of the glandular lumen in the excretory duct is perceptible in only a few primordia of the sweat glands.

Hypogastrium (Fig. 36):-The primordia of the sweat glands attain the region as deep as the hair bulbs do. The best developed primordia of the sweat glands have a glandular lumen, which is surrounded with a layer of the short columnar epithelial cells. Most generally recognized primordial sweat glands have a glandular Iumen, which is surrounded by an epithelial cell layer or several cell layers showing an irregular form. In most of the excretory tubules which adjoin the glandular lumen, surrounded by a layer of the epithelial cells, the excretory tubular lumen comes into view. The excretory tubule ascends 
along the hair and opens its orifice into the hair follicle at the region one-third or fourth above the hair. Inside the glandular lumen a few eosinophil substances are found. Generally the glandular lumen on this region, that is, hypogastrium, is larger than that of the other regions of the body.

Back (Fig. 37) :-The primordia of the sweat glands attain a portion as deep as the hair bulbs do. The primordia of the sweat glands in the best developed stage have a glandular lumen, which is surrounded by a layer of flat and short columnar epithelial cells. The excretory tubular portion which connects with the glandular lumen is composed of two clear layers of cells. On both portions, glandular lumen and excretory tubular portions, the cytoplasm which faces the inner lumen of the epithelial cells stains deeply with eosin lineary. The thickness of the cell layer at the transitional region from the glandular lumen to the excretory tubular portion, is thinner and longer than that on the other parts of the body. Most recognized primordia of the sweat glands have an irregular glandular lumen which is surrounded by several layers of cells. The excretory tubule opens its orifice into the hair follicles near the region one-fourth above the hair.

Sole (Fig. 38):-The primordia of the sweat glands reach the region as deep as the hair does. The primordia of the sweat glands in the best developed stage, have a glandular lumen which is surrounded by a flat epithelial cell layer and by the myoepithelial cells which surround the external side of the epithelial cells. The primordial sweat glands in which an irregular glandular lumen surrounded with several cell layers is recognized, are most perceptible on the sole. The excretory tubule open its orifice into the hair follicle at the one-fourth portion above the hair.

From the descriptions mentioned above, the figures in this period are alike to the previous period. However there are some different points, in that the primordia of the sweat glands which have a glandular lumen surrounded by a layer of the epithelial cells appear on the abdomen, hypogastrium and back, and that on the parts, where the primordia as mentioned before, appeared already in the previous period, the number of the primordia decreases in this period, and that on the sole, the clavate primordia of the sweat glands are perceptible no more. On the forehead and hypogastrium some eosinophile substances are found in the glandular lumen. 
VII. The figures of the cattle embryo which is $80.2 \mathrm{~cm}$ in the body length and $25180 \mathrm{~g}$ in the body weight.

(End of the eighth fetal month, specimen number 37)

Forehead (Fig. 39):-In this period the glandular lumen which is surrounded by a layer of short columnar epithelial cells and by myoepithelial cells which surround the external side of the epithelial cells, is formed on almost all the primordia of the sweat glands. However, the glandular lumen which is not yet surrounded by a perfect layer of epithelial cells and in which the nucleus has a weak stainability, is sometimes recognizable. The epithelial cells are flat and their nucleus is round or elliptic. At the region which faces the glandular lumen the cytoplasm stains more intensively with eosin, than that of the other parts. The myoepithelial cells are flat ones which have a flat triangular, or spindle shaped nucleus. Their cytoplasm has a weaker stainability as compared with that of the epithelial cells. In the cytoplasm the myofibrils are not found. The cytoplasm which faces the glandular lumen of the glandular epithelial cells stains more deeply with eosin than that on the other regions. The excretory tubule consists of two layers of cells. The cells of the inner layer are short columnar and their nucleus is round. The cytoplasm which faces the excretory tubular lumen stains deeply with eosin and the thickness of the staining with eosin is thinner than that in the glandular epithelial cells. The cells of the external layer of the excretory tubule are flat and contain an elliptic or flat nucleus. The arrangement of the cells is more systematic and more dense than that of the myoepithelial cells at the glandular corpus.

On the transversally cut-sections of the skin in this period, many sections of the glandular lumen are found and they are considered to form a "Knäuel," while on the longitudinally cut-sections the formation of "Knäuel" is not recognizable that is, one excretory tubule has the glandular corpus which has only one glandular lumen and it is not recognizable even on the figure from which one secretory tubule branches off. The excretory tubule opens its orifice into the hair follicle near the region about one-fourth or fifth above the hair. The construction of the excretory tubule does not vary on its full length. The specific structure which was recognized in the previous period at the transitional region between the excretory tubule and the glandular corpus on the parts of the body is recognized too in this period. Inside some glandular lumens, the eosinophile substances are a little perceptible, but no shed epithelial cells are found. Among the myoepithelial cells the intercellular secretory tubule is not perceptible. Around the completed glandular 
lumen the proper membrane is recognizable as the substance which does not stain with eosin or sometimes stains filamentous.

Breast (Fig. 40):-The primordia of the sweat glands reach the region as deep as the hair bulbs do. On the best developed primordia of the sweat glands the glandular lumen which is surrounded by an epithelial cell layer is found very seldom, or only in small numbers. Most recognized primordia of the sweat glands have a glandular lumen which is of a cleft-form or of an irregular type. The epithelium is not yet a perfect layer, and besides a few cells in which the nucleus has a weak stainability are found in the glandular lumen. No primordia of the sweat glands, which are without lumen are found. The exceretory tubule opens its orifice into the hair follicles at the region half or one-third above the hair roots.

Abdomen (Fig. 41) :-Most of the primordia of the sweat glands which are recognized on the abdomen have a glandular lumen surrounded with a layer of the epithelial cells. Sometimes the primordia of the sweat glands which have an irregular glandular lumen surrounded by several layers of the cells are found but no clavate primordia. The exceretory tubule almost opens its orifice into the region one-third or fourth above the hair follicles.

Hypogastrium (Fig. 42):-The primordia of the sweat glands get to the region as deep as the hair bulbs do. Most of the primordia of the sweat glands on the hypogastrium have a glandular lumen which is enclosed by a layer of the glandular epithelial cells. Similarly the excretory tubule is generally composed of two distinct layers of the cells. Though only few, the primordia of the sweat glands have an irregular glandular lumen enclosed by several layers of the cells. Moreover, the primordia in which the glandular lumen is considered to contain eosinophile substances are found. The excretory tubule opens its. orifice into the hair follicle near the portion one-fourth above the hair capsule.

Back (Fig. 43) :-The primordia of the sweat glands get to the region as deep as or more deeper than the hair bulbs do. The best developed primordia of the sweat glands have a glandular primordia lumen which is enclosed by a layer of the epithelial cells, while most of the primordia of the sweat glands have an unsystematic glandular lumen, which is surrounded by a number of cell layers and inside the lumen the nucleus which has a faint stainability is perceptible. Sometimes the hook-shaped primordia of the sweat glands which have a cleft-like glandular lumen are found. At the transitional region between the excretory tubule and the glandular corpus, a narrow portion of the glandular lumen which is enclosed by the wall of the cell layers is distinctly noticeable (Fig. 42). The excretory tubule opens its orifice onto 
the portion one-third or fourth above the hair capsule.

Sole (Fig. 44):-The primordia of the sweat glands reach into the region as deep as upper side of the hair bulbs. The best developed primordia of the sweat glands have a glandular lumen which is surrounded by a layer of the glandular epithelial cells, but these are rarely found on this part of the body. Most of the primordia of the sweat glands have a cleft-like or irregular shaped glandular lumen which is enclosed by several cell layers. Moreover on most of the primordial sweat glands a weak staining nucleus is perceptible in the glandular lumen. Generally the glandular corpus in the primordial sweat glands on the sole shows a flat elliptic form and the round or oval glandular lumen as shown on the other parts of the body is not found. The excretory tubule opens its orifice into the hair follicles near one-third of the portion above the hair capsule. From the delineations mentioned already, on the forehead, the earliest developed primordia of the sweat glands is recognized numerously, while on the other parts of the body, except the back and sole, the developmental grade in the primordia of the sweat glands is about the same. On the sole and back the latest developed primordia of the sweat glands, that is, the primordia in which a cleft like and irregular shaped glandular lumen is perceptible, is found. On every part of the body the primordia of the sweat glands do not form "Knäuel."

Judging from the relative position with the length of the hair and the region, where the excretory tubule opens its orifice into the hair capsule, the forehead is the upmost region, where the tubule opens its orifice into the hair capsule. On the other parts of the body its opening positions are similar to each other while on the sole it opens into the more lower region than on the other parts.

\section{DISCUSSION}

On the study of the external ears, external nose and other parts on the face of the human embryos, Akagi (1939) observed that the region where the primordia of the sweat glands appeared for the first time at the bow of the eye in the four month old human fetus (S.F.L. $100 \mathrm{~mm}$ ), and the forehead (S.F.L. $123 \mathrm{~mm}$ ), zygomatic portion, cheek, lubulus auriculae (S.F.L. $126 \mathrm{~mm}$ ), region of the masticatory muscle of the parotid gland (S.F.L. $133 \mathrm{~mm}$ ), chin (S.F.L. $13.6 \mathrm{~mm}$ ), vestibulum nasi (S.F.L. $148 \mathrm{~mm}$ ), external auditory meatus (S.F.L. $164 \mathrm{~mm}$ ) followed. He further said that in the external auditory meatus of all the five or more month-old embryos the apocrine glands were recognized and on the auricle, though the regional 
findings varied, in the sixth fetal month a few apocrine glands were perceptible everywhere, and on the chin, zygomatic portion, cheek and region of the masticatory muscle of the parotid gland, the highest stage of the glands was at the middle of the fifth fetal month then it began to retrogress.

In reference to the ceruminous glands Alzheimer (1888) reported, that they originated from the epithelial cells on the external root sheath of the hair capsule in the five to six month old human fetus.

Iwata (1933), in the sixteen week-old fetus, recognized for the first time the primordia of the ceruminous glands being turgid as the "solide Zapfen" of the broad base at the side of the hair bases in the stage of "Hiarzapfen:"

Morise (1955) reported, that the sweat glands in Rhinolophus Kosidianus were only apocrine glands which originated from the hair capsule but their regions of origin were limited to the cheek and its peripheral region and the time when the gland-buds belonged to the stage of "Haarzapfen."

Nagai (1936) when describing the origin of the sweat glands in the upper limbs of the human embryos, said, the glands formed the "Haarzapfen" in the fourth fetal month and on the axilla they originated in the next. At the end of the fifth fetal month the apocrine sweat glands arose from every part of the upper limbs in accordance with the morphological period.

Kan (1941) said, that the apocrine glands in the axillary region were recognizable in conditions of tubercular or restiform appendage at the obtuse angle side, where the hair bases crossed with the epidermis in the beginning of the fifth fetal month.

Furthermore, Iwata (1933) asserted that the primordia of the sweat glands arose from the anus in the sixteen week-old fetus. Alverdes (1934) reported, that the apocrine glands on the vestibulum nasi occurred for the first time in the human fetus of $140 \mathrm{~cm}$ in body length. The primordia of the large sweat glands were found on the vestibulum nasi of the five month old human embryo according to Mogi (1939) and were found in the axillary region of the human fetus of $22.0 \mathrm{~cm}$ in body length according to Steiner (1926).

On the cattle embryos observed by us, the forehead, breast, abdomen, hypogastrium, back and sole were studied. There, all the primordia of the sweat glands occurred from the hair bases and secondarily they were recognizable as hill-like cell groups of the broad basement at the obtuse angle side of the hair bases. The regions where the primordia of the sweat glands were noticed in the earliest time, were the forehead and sole of the cattle fetus which 
was $22.3 \mathrm{~cm}$ in body length (middle of the fourth fetal month) and those of the abdominal region followed. Namely, from the consideration about the fetal month, it was recognized that the origination of the sweat glands was about the same period as that of the findings mentioned above. On the region, where the sweat gland springs up for the first time, Akagi (1939) reported that it arose on the brow of the eye in the fourth fetal month (100 $\mathrm{mm}$ in the body length) for the first time, and the forehead and chin followed, on the other hand some reports indicated, that on the embryo of four to five fetal months it appeared on the "Fingerbeere" (Blaschko, 1888), palm (Greefberg, 1883), sole (Kölliker, 1889).

On the general development of the sweat glands, Greefberg (1883) reported, that every sweat gland of the human embryo possessed its own developmental process so that it did not originate from every part of the body at a time. Blaschko (1887) said, that the sweat glands in the extermities of the body reached the best development. Wimpfheimer (1907) assured, that on the "Katze, Rind, Schaf and Schwein" the sweat glands arose from the hair capsules and that remarkable regional varieties existed in the same body, namely, in the human embryo which was $22 \mathrm{~cm}$ in body length (ScheitelSteisslänge) and had no sweat glands on its parietal portion, on the occipital portion, the sweat glands existed already, while on the other embryo which was $23.5 \mathrm{~cm}$ in body length, in spite of the numerous long sweat glands existing on the temporal portion, on the occipital portion only a few sweat glands were recognizable.

Morioka (1935) also reported, that in comparision with the sole and the axilla of the same embryo, the sweat glands on the former arose preceding those on the latter, besides, on the same part of the same body developmental difference in the sweat glands existed.

Backmund (1904) pointed out, that the sweat glands on the maxilla and mandibule of the cat embryo arose extraordinarily early.

In the investigations on our cattle fetus the regions where the primordia of the sweat glands originated for the first time, were the forehead and sole, out of the six regions of the body, but as compared with both regions the best developed primordia of the sweat glands were recognizable on the forehead, while the primordia on the sole came later than those on the formar, but the number of the primordia were more numerous. Therefore, we will not venture to say, that the sweat glands on the extremities of the body reach the better development as assured by Blaschko (1887), because of the facts, that the best developed primordia of sweat glands on our cattle embryos were 
perceptible on the forehead. Though on the forehead the development of the sweat glands after the arising was always ahead of the other parts of the body in the same period, on the sole the development gradually began to fall with the fetal months' advancing, and in the eighth month the sweat glands on the sole was counted among the latest developed ones.

Next to the forehead and sole, the abdomen had the primordia of the sweat glands which showed the earliest form, but on the breast, hypogastrium and back the primordia of the sweat glands were not yet perceptible.

Generally the decision on the originated period of the primordial sweat glands is difficult. Stöhr (1903), Pinkus (1927), Nagai (1936), Ueda (1939) and others recognized the reticular bunch (Rete-leiste) which arises inside the epidermis as the primordia of the sweat glands. However in the early fetal months there are morphological similarities among the primordia of the sweat glands, of the hairs and of the sebaceous glands so that their diagnosis are difficult. The primordia of the sweat glands which we recognized were perceptible as the broad basemental cell groups at the obtuse angle side where the hair bases in the stage of "Haarzapfen" crossed with the epidermis and those are considered to be in correspondence with Iwata's "solide Zapfen," erste solide Anlage (1933). According to Ellenberger (1911) these primordia of the sweat glands have no "Papillenanlage" as noticed in the hair bases at the apex of the cell group and he says, that these primordia of the sweat glands are able to be distinguished from the hair bases. According to Morise (1955) and Ueda (1939), on the primordia of the "Trommel stockartig" drumstick like kind, in the dermis around the apex of the primordia of the sweat gland there exist fewer connective tissues than around the hair base. The cells of the connective tissues are situated at some distance of the primordia of the sweat glands. Added to these reports we observed that the cytoplasm in the primordial sweat glands had a somewhat stronger stainability for eosin, then compared with that in the hair bases and that the melanophoren which were visible in the hair bases were never found in the primordia of the sweat glands so that they were distinguished from one another.

The primordia of the sebaceous glands arise for the first time from the hypogastrium of the embryo which is $43 \mathrm{~cm}$ in body length (middle of the fifth fetal month) and though they are given to rise from the root of the hair bases, they are in a somewhat lower part of the inserted portion of the primordia of the sweat glands. The budding portion of the primordia of the sweat glands are not always on the obtuse angle side of the hair bases but on everyside of the hair bases. The cells in the budding portion are 
larger and more round than those of the primordia of the hairs and sweat glands and the cytoplasm stains the fine granular orange with eosin. The nucleus which locates at the center of the cytoplasm, is round.

In one or two cells at the central region of the cell group of the sebaceous glands the cytoplasm stains lightly and shows "Beginn einer fettigen Degeneration." When the primordia of the sebaceous glands come out, the primordia of the sweat glands is showing already a spherical or clavate form. From these points it is comparatively easy to distinguish the primordia of the sweat glands from the hair bases or from the primordia of the sebaceous glands in the cattle embryos.

The origin and classification of the sweat glands have been studied by many scientists. They termed the sweat glands "Schlauchdrüse" or "Knäueldrüse." Some investigator divided the sweat glands into the "merokrine Drüsen" and "holokrine Drüsen" according to the glandular form in the secretory period. Schiefferdecker (1922) divided the "merokrine Drüsen" into the "ekkrine Drüsen" and the "apokrine Drüsen."

Schaffer (1924) divided the sweat glands into two groups, one of which was "monoptische Drüse" composed of a single layer of the glandular cells, and another one was the "polyptische Drüse" which was composed of several layers. Alzheimer (1888) reported genetically that the ceruminous glands of the human embryo differed from the other sweat glands, arising with the hair base. After then, many investigations on the sweat glands of the mammalia have been done and it was found, that the developmental process in the ceruminous glands observed by Alzheimer was similar to that in the sweat glands of the mammalia. Marks (1895) found, that all the hairs, sebaceous glands and sweat glands on the mammalia arose from the "Epidermiszapfen" and he named them "primärer Epithelikeim." Stöhr (1903) also reported that the apocrine sweat glands sprang up from the hair base secondarily. Schiefferdecker (1922) termed the sweat glands which arose from the "primärer Epithelkeim" (Marks 1895) as the "grosse Schweissdrüse," and termed the sweat glands which has the root directly on the epidermis as the "kleine Schweissdrüse." Moreover he named them the "apokrine Schweissdrüse" based on the specific "kuppelförmige Sekretion" which was shown in "grosse Schweissdrüse" of the human and in the sweat glands of the animals.

Valentin (1835) asserted that the human cuticular glands originated as the round "Gruben" with a conical hole in the middle or end of the fourth fetal month with taking the contrary direction to the hairs'. Kölliker (1850) stated that the sweat glands on the hairless parts, that is, the sole and the 
palm, originated from the epidèrmal malpigian layer as the substantial bunch and they were yellow semitransparent substances, which were completed with the hair base.

Maurer (1892) declared, that the sweat glands were a direct production of the epidermis and that they sometimes arose from the hair tips or ends so that they were entirely different from the sebaceous glands in their origin.

Backmund (1904) studying the cats-sweat-glands, decided, that on the haired portions the external cells of the hair papilla gave rise to the nuclear division and then gave rise to the sweat glands as the lateral processus, whose starting portion was located directly or about under the columnar cells of the epidermis, and it was more narrow than the hair, being turgid at the half end portion. Rarely on the haired portions the sweat glands sprang up. He said moreover, that on the sole the sweat glands had their mother foundation in the epidermal layer. After then, Steiner (1926), Alverdes (1932), Iwata (1932), and Sperling (1935) have been studying on the sweat glands, and reported, that in man the apocrine glands were formed in definite portions in a close relation with the hairs and the sweat glands in conjuction with a broad tubular form, and the appex of the sweat glands formed the "Apokrine."

As for the cattle sweat glands, Wimpfheimer (1907) has reported this investigations. Especially Wimpfheimer found, that it was a fact, that the sweat glands arose from the hair capsules, and their starting portion was the transitional part between the hair papilla and the epidermal layers and another was the deeper portion of the hair papilla.

On our study about the skin of the cattle embryo, though the sweat glands arise from the hair anlagen secondarily on all six parts of the body, some of the primordia of the sweat glands on the forehead and abdomen in the cattle embryo which is $27 \mathrm{~cm}$ in body length (beginning of the fifth fetal month) are recognizable at the transitional parts between the epidermis and the hair bases. However, the primordia of the sweat glands which arise from the epidermis independent of the hairbases, are never found. According to Ellenberger (1911), Abschnitt of Sehweisstubuli on the sweat glands in the cattle are very large ones and somewhat bend like on "S." The epithelial cells being "platten förmig," the glandular lumen is broad. "Ausführungs gang" is $10-15 \mu$ in its diameter and that boundary line with the secretory portion is distinct and the orifice of the excretory tubular portion opens with the sebaceous glands. Gurlt (1835) asserted that the sweat glands on the external public portion of the cattle were very small and round, and that though "Ausführungs- 
gang" of the sheep had a coiled shape, those of the cattle showed only bending figures. In our research, the sweat glands are simple tubular glands and in the eight month-old cattle embryo the sweat glands are oval or egg-plant shaped but rarely show an $\mathbf{S}$ like figure. Though it is impossible to comment on the wideness of the glandular lumen of the glandular corpus correctly, because of it being not measurable, it is considered to be a large one. The glandular epithelial cells are flat as assured by Ellenberger, and the formation of the glomerule is not recognizable in the glandular corpus, on the other hand on the excretory tubule a coiled figure is not perceptible but only a curvate one. The boundary region between the glandular corpus and the excretory tubule is not distinct as described by Ellenberger but there, a specific structure, where a narrow glandular lumen composed of the wall of the cell layers is found, exists in the boundary region.

From the description mentioned above, the sweat glands of the cattle embryos on the observation, until the eighth fetal month at least, belong genetically to "apokrine Schweissdrüse" out of the "merokrine Drüse" which was pointed out by Schiefferdecker (1922) and belong to the "monoptische Drüse' which was asserted by Schaffer (1924), while the distinct secretory figures in the glandular cells are not yet recognizable, namely, in the glandular lumens any other secretory substances are not recognizable either.

On the orific region of the sweat glands into the hair follicles, Alzheimer (1888) said that the time, when the opening region of the cerminous gland into the hair capsule ascends and opens directly into the epidermis was in infancy for the first time and it was completed at puberty.

Eggeling (1904) reported that the orifice of the sweat glands which opened into the hair capsule gradually ascended during fetus time, and the orifice when reached the epidermis at last, the relation with the capsule faded out.

Diem (1907) assured that on the head of the human embryos, the orifice of the sweat glands accompanying the hair bases seldom ascended and opened directly on to the epidermis. Steiner (1926) reported that "apokrine Drüsen" on the axilla, labia majora and scrotum at first opened their orifice into the hair bases and their opening portion gradually ascended with the fetal month, then at last opened onto the epidermis. On the other hand, Wimpfheimer (1907) pointed out, that in the various mammalia all the sweat glands arose from the hair follicles and some of which opened their orifice onto the surface of the epidermis independent of the hair follicles. Maurer (1895) stated that the ontogenesis of the sweat gland at first arose from the hair 
follicles as repeating the "phylogenetische" changes and then gradually were independent of the hair follicles. Backmund (1904) said that on the cats the sweat glands arose from the hair bases and their orifice gradually removed to the surface of the cuticle. Diem (1907) assert that on the animals except in bat "Fledermaus" and man, most of the sweat glands which opened onto the epidermis at "behaart" portion arose from the hair bases and a few of them arose from "Basalzellen" exceptionally, but the figures to which the orifice ascended and opened directly on to the epidermis were very few. Carossini (1912) stated, that on the human embryos, though most of the sweat glands which arose with the hair follicles faded out during the fetal life, it was not true that the sweat glands which arose on the axilla and the scrotum remained they were and when they gave rise to the greater sweat glands they turned to other parts.

Sperling (1935) suggested, that the hairs which had to do with the apocrine sweat glands, often were replaced by other hairs because the orifice of the glands was pushed into the inner epidermis from the funnel-shaped portion of the hairs. Kan (1941) recognized the primordia of the sweat glands at the transitional region between the hair follicles and the epidermis on the axillary portion of the six month old human fetus. He, therefore, said that because these primordia of the sweat glands showed a similar development to the sweat glands which opened their orifice into the hair follicle in the same period the apocrine sweat glands which opened into the hair follicle would be considered to be on their removing way, but such a finding was rare, and not found in the adult body.

Gurlt (1835) asserted that on the various animals the sweat glands always opened their orifice onto the free surface. On the dogs Ledig (1875) argued that the sweat glands opened their orifice on the upper part of the hair follicles and on the calf they opened their orifice into the hair follicles which were far deeper than the orifice of the sebaceous glands. On the developmental study on the Rhinolophus Kosidianus. Morise (1955) has reported, that all the apocrine sweat glands in the earlier time arose from the hair follicles and their originated portion was the upper-most portion of the hair base, on the other hand, on the embryos in the end of the last fetal month or on the adult animal the orifice of the sweat glands was recognizable in the hair folliclar triangular portion and on the surface of the epidermis near the former portion, but not recognizable contracted part of the hair base, so that the opening portion of the sweat glands is probably moved a little. Morioka (1935) reported, that on the axillary glands of the human embryo, the excretory tubule ascended with the 
waving curvature and though it followed each developmental point of the primordia or poured itself on the surface of the epidermis or into the hair follicle. In the case of pouring into the hair follicle, the figure of the excretory tubule poured into the depressed portion of the hair follicle or into the near portion over its starting place. In our observations, the excretory tubule is considered to open its orifice on the transitional region between the hair and the epidermis in the period, when it does not reach the end of the fetal life. This finding is not often, but not rare. Moreover, the circumstances in which the excretory tubule opens its orifice under the sebaceous gland are not recognizable in any parts of body as mentioned by Ledig, but the circumstance which the excretory tubule opens its orifice into the hair follicle with the sebaceous gland or opens into the hair follicle ascending through the lobules of the sebaceous gland or into the part near the opening portion of the hair follicle to the epidermis is observed.

Accordingly, on the cattle embryos most of the sweat glands spring up from the hair bases but sometimes they are considered to arise from the transitional region between the hair bases and the epidermis in relation to the direction in the cutting sections. Though in the later period of the fetal life the excretory tubules almost open their orifice into the hair follicle at one fourth or half of the portion above the hair, they also open their orifice into the transitional region at the portion very near the hair orifice to the epidermis. Therefore, the running direction and opening portion of the excretory tubule are more or less removed with the advancing of the fetal month. But it is not clear, whether the sweat glands which arose from the transitional region between the hair folliale and the epidermis in the early time, develop as it is, like the figure as mentioned above.

About the cause of the transition in the orifice of the sweat gland according to Stiner (1926) "Flächenwachstum" of the epidermis in the later period of the fetal life is so rapid as compared with the origin of the sweat gland, that the number of the sweat gland per $1 \mathrm{~mm}^{2}$ decreases. Taniguchi and Mochizuki (1937) reported, that from the data which measured the number of the excretory tubule in the fetal sweat glands following the fetal months, the greatest figure was on the head and trunk in the seven month-old embryo and on the extremities in the eight month-old fetus, after then, the more the fetal months advanced, the less the number of the excretory tubules decreased. Morise (1954) asserted, that with regard to the development of the skin appendage on the animals, its primordia which was developing gradually in the middle of the fetal life, developed rapidly at the end of the last fetal month, accordingly, the finding 
about the animals at the end of the fetal life was more difficult to observe, as compared with that of the human body. Also Akagi (1939) reported, that after the embryo had attained the beginning of the fifth fetal month, apocrine sweat glands on the chin, zygomatic portion and the region of the masticatory muscle of the parotid gland gradually decreased. These reports suggested the rapid changes in the "Flächenwachstum" in some period on the developmental process.

In our observation, we don't count the number of the sweat gland in every fetal month and observe neither the developmental rate in the sweat gland nor "Flächenwachstum," so that there is no contest. However it is necessary to take in the consideration, that the sweat glands in the cattle embryos seemed to arise from the transitional region from the epidermis to the hair bases.

On the degradation of the primordia of the sweat glands, Pinkus (1926) stated on this matter that the apocrine sweat glands usually degenerated but sometimes: they were preserved. According to Schiefferdecker (1922) in the hair on the body the apocrine sweat glands arise from the hairfollicles and degenerate in the end of the fetal life. Steiner (1926) reported, that the apocrine sweat glands on the axilla, labia majora and scrotum transfered to the upper part of the hair bases during the fetal life and opened their orifice onto the surface of the epidermis, on the other hand the apocrine sweat glands on the inguinal region of the human body probably degenerated but the ecrine and apocrine sweat glands on the axillary region and the apocrine glands on the labia majora and on the scrotum increased gradually. Akagi (1939) described, that on the face of the human embryos, comparatively many primordia of the sweat glands arose at the region of the external ear and of the face from the middle of the fourth fetal month to the end of the fifth, while in the later period of the fetal life the apocrine sweat glands degenerated at the regions except the vestibulum nasi and the external auditory meatus. Moreover, he said, that on the figures of the degradation the apocrine sweat glands which composed the hair glomerule at the chin, zygomatic region, cheek and region of the masticatory muscle of the parotid glands, were very few and most of them only showed the vestiges of short irregular shaped projections at the neck portion of the hair root.

Morise (1955) assured that on Rhinolophus Kosidanus, the apocrine sweat glands sprang up on the whole body, while except the sweat glands on the cheek and its peripheral region, the apocrine sweat glands degenerated to mere vestiges. In our investigation the vestiges of the primordia of the sweat glands were not recognizable on the cattle embryo of the sixth fetal month, contrary to Pinkus, Schifferdecker, Stiner and Akagi's assertions on the body of the 
human embryos and Morise's on the body of the Fledermaus except the cheek that there were some vestiges.

On such materials as mentioned above, the apocrine sweat glands remained on the specific regions of the body during the developmental process, while on the cattle embryos only the apocrine sweat glands were recognizable on the six parts of the body even though after the embryos grown up, so differed in the distribution of the sweat glands that the finding of the sweat gland was difficult.

Relation with the apocrine sweat glands and hair bases: Backmund (1904), Eggeling (1904), Diem und Wimpfheimer (1907) reoprted that a hair base on the human and mammal embryos generally gave rise to a primordia of the sweat glands. Brinkmann (1909) found in the monkeys that a hair base sometimes gave rise to many primordia of the sweat glands. Iwata (1933) insisted that a hair base on the ceruminous glands of the human embryo which was $15 \mathrm{~cm}$ in body length, gave rise to two primordia of the sweat glands. Mogi (1939) also obtained similar findings on the sweat glands at the vestibulum nasi.

Kan (1941) has reported as follows, two primordia of the sweat glands on the six month-old embryo of man open their orifices on the same side of a hair follicle with lying one upon another. The primordia of the sweat glands near the hair follicles show a coiled shape, which is turgid clavately at the apex of the primordia, while at the ampulla of the apex of the primordia the formation of the glandular lumen is found.

In our study on the cattle embryos, a hair base gives rise to only a primordia of the sweat glands but not two or more. Moreover, the figure in which the excretory tubules of two sweat glands are united into one and open their orifice into the hair base, was never found. It was not observed, whether a hair base always gives rise to a primordia of the sweat gland or not. But in the later period of the fetal life a hair base does not always gives rise to a primordia of the sweat glands on the sections and the number of the sweat glands in a scope seemed to be fewer than that of the hair. These facts suggest that the orifice of the sweat glands has a probability to transfer to the epidermis and that the direction on the sections or the existence of the degenerated phenomenon are worthy of attention. However, from only these observations we can not determine correctly.

About the direction of the clavate primordia of the sweat glands Kölliker (1850) on the human body and on the higher animals, Backmund (1904) on the cat embryos, Ueda (1939) on the human embryos and Morise (1954): on the bat, said, that the figures of the primordia of the sweat glands met at right angles with the surface of the epidermis. On the contrary, in our cattle embryos. 
the nipple like primordia of the sweat glands met with the surface of theepidermis perpendicularly, while the clavate primordia of the sweat glands generally ran parallel to the hair base.

Period when the apocrine sweat glands present nipplelike or clavate form: Ueda (1939) insisted that it was from the seventeenth week of the fetal life to the twenty-second. Akagi (1939) reported that it was from the fourth fetal month to the fifth. Clausen and Alexanderson (1932) asserted, that it was till the end of the third fetal month. Morise (1955) argued that there were probably remarkable personal and racial differences as for the period of the development of the sweat gland.

In our investigation though a few nipplelike primordia of the sweat glands were recognized, yet on the breast and hypogastrium of the embryo in the middle of the fifth fetal month, after that month the nipplelike primordia of the sweat glands were not recognized. Many clavate primordia of the sweat glands were still recognizable in the embryo in the middle of the sixth fetal months but not recognizable in the middle of the seventh fetal month.

Accordingly, in our materials the period, when the apocrine sweat glands. present nipplelike or clavate shape, is later than the period found in other investigators' materials and even though Morise's assertion, mentioned above, is taken into consideration, in the cattle embryos the clavate primordia of the sweat glands are recognizable until the later period as compared with thosein the human embryos. However, as will be shown later, the period of the formation of the excretory tubular lumen is much the same on both human embryos and cattle embryos, so that on the cattle embryos the primordia of the sweat glands seems to develop exceedingly in the later period, especially in the last stage of the fetal life.

About the bending at the apex of the primordial sweat glands: Köliker (1850) on the sole of the six month-old human embryos, Greefberg (1883) on the sole of the embryo which was $15 \mathrm{~cm}$ in the body length, Pinkus (1910) on the palm and sole of the six month-old embryo, Hertwig (1910) on the palm and sole of the seven month old embryo, Aurell (1938) on the sole of the fetus of $20 \mathrm{~cm}$ in -the body length, found the bending at the apex of the primordia of the sweat glands. Kan (1941) reported, that the bending at the apex of the apocrine sweat glands on the axillary region of the human embryo was recognizable in the end of the fifth fetal month and in the sixth fetal month the bending was found in the median portion of the sweat glands.

In our research a few primordia of the sweat glands which bend at the apex of the primordia was found in the sole of the embryo in the middle of 
the fifth fetal month and on the forehead and hypogastrium some primordia of the sweat glands bent laxly. In our cattle embryos as well as in the human embryos, the figures which the sweat glands began to bend on the sole (hairy portion) comparatively in early time, at the same time on the forehead and hypogastrium the bending of the sweat glands was recognized.

Kan (1941) asserted that on the apocrine sweat glands on the axilla of the human embryo the bending at the medium part of the glands were recognized in the seventh fetal month. The primordia of the sweat glands began to bend at the apex at first, then at the median parts. He said that these findings were in accordance with Pinkus's findings (1910).

However, Aurell (1938) reported, that the bending at the apex and the median region of the sweat gland began at the same time. Kölliker (1850) disputed that the beginning of the flexion at the middle region of the sweat glands was rather earlier than that on the apex of the sweat gland.

In our cattle embryos, the flexion at the median part of the gland was recognized in every part of the embryo in the middle of the sixth fetal month. Namely, in the cattle embryos as asserted by Pinkus and Kan the sweat glands begin to bend at the apex at first, then at the median part of the sweat glands.

Cause of the bending at the apex of the primordia of the sweat glands: Becker (1921) described that cause of the bending at the apex of the primordia of the sweat glands was attributable to the fact, that the connective tissue fibers in the dermis ran parallel with the surface of the epidermis and to the fact that the primordia of the sweat glands developed vigorously. Aurell (1938) considered it to be caused by a simple mechanical factor. Ueda (1939) ihsisted that the flexion of the sweat glands began at first at the transitional region between the apex and the median part of the primordia of the sweat glands and that at the adjacent region to the flexion some blood vessels existed, so that the bending had a close relation with the blood vessels.

Kan (1941) differed with Ueda, that though some capillary vessels were recognized in the region near the apical bending portion, it was hard to say that existence of the capillary vessels caused the bending of the primordia of the sweat glands because the vessels did not always exist there. On the contrary, the capillary vessels stood against the bending of the primordia. He also said that we, therefore, ought to search for the cause in a rapid development of the dermis.

In our findings on the cattle embryos, we have about the same opinion as in the reports mentioned above. But it is hard to say, that the cause arises from the existance of the blood vessels at the adjacent region to the flexion, or 
is distributed to the rapid development of the dermis. We ought to take into the consideration the inducing relation with the hair bases, tendency in the primordia of the sweat gland itself and other causes which are considered in case of the development and growth in living things.

About the region where the glandular lumen is composed for the first time: On the apocrine sweat glands Alverdes (1932) and Morioka (1936) reported, that the glandular lumens arose at the apex of the primordia as narrow spaces. Backmund (1904), Diem (1907), Becker (1921), Mogi (1938), Pernkopf and Palzelt (1934) described that on the eccrine sweat glands the glandular lumen originated from the apical portion of the primordia.

On the other hand, Ueda (1939) insisted, that they were recognizable at the transitional region between the apex and the median portion of the primordia only in case of primordia bending. Kölliker (1850) and Wimpfheimer (1907) recognized the formation of the glandular lumen on the surface of the epidermis and at the apical portion of the primordia. Tawara (1932) reported that the glandular lumen was formed for the first time at the region which was become the tubule on the Moll's gland. Kan (1941) said, that the glandular lumen was formed at the transitional region between the apex and the median portion of the apocrine and eccrine sweat glands. Morise (1955) reported on Phinolophus Kosidianus that the initial formation of the glandular lumen was found at the apex of the ampulla of the primordial sweat glands.

In our study on the cattle embryos, the initial region of the formation of the glandular lumen was in the cell groups of the transitional region from the root portion of the ampulla to the median portion of the primordia of the sweat glands as a narrow cleft longitudinally, while at the apex of the ampulla the initial formation of the glandular lumen was not seen. Namely, it is hard to say wether the initial region of the formation of the glandular lumen is the apical ampulla or the median portion of the primordia of the sweat glands. On the clavate primordia of the sweat glands the nucleus of the groups at the apical ampulla was abundant in chromatin but could be seen that the cells, which had a nucleus, having a strong stainability from the ampulla to the median portion of the primordia of the sweat glands, had a tendency to increase. Moreover, as insisted by Ueda (1939), the glandular lumen was riot always recognizable only in case of bending at the apex of the primordia, especially on the sole, the glandular lumen had a tendency to be seen in the comparatively straight primordia of the sweat glands.

On the period, when the glandular lumen originates for the first time: On the apocrine sweat glands, Contino (1907) on the ciliary gland of the $13.0 \mathrm{~cm}$ 
embryo, Steiner (1926) on the sweat glands on the axillary region of the embryo in the end of the fifth fetal month, Tawara (1932) on the ciliary gland of the twenty-week-old fetus, Iwata (1933) on the ceruminous gland of the twenty-oneweek-old embryo, Alverdes (1934) on the nasal vestibular glands of the $16.5 \mathrm{~cm}$ human embryo, and Mogi (1938) on the nasal vestibular glands of the human embryo in the fifth fetal month recognized the initial formation of the glandular lumen.

Morioka (1936) reported, that the origination of the glandular lumen of the apocrine sweat glands on the axillary region took the same time as the formations of the capillary ducts and horny hairs. Backmund (1904) and Diem (1907) on the cat.fetus and on the ram fetus, respectively, reported that the glandular lumen originated in the time when the hair base was in the stage of "Haarbulbuszapfen." Morise (1955) on Rhinolophus Kosidianus described, that the formation of the glandular lumen belonged to the stage of the "Haarbulbuszapfen." Kan (1941) reported, that the glandular lumen of the apocrine sweat glands on the axillary region occured at the end of the fifth fetal month, and this was at the same time as the formation of the bending at the apex.

On the eccrine sweat glands, Kölliker (1850) on the soles of the human embryo in the sixth fetal month, Greefberg (1883) on the soles of the $25 \mathrm{~cm}$ human embryo, Pinkus (1910) and Fischel (1929) on the palms and soles of the seven-month-old embryos, and Becker (1921) on the upper arms of the six-month-old human' fetus, could see or observed the glandular lumen.

In our observation on the cattle embryos the first glandular lumen was seen on the forehead of the embryo in the beginining of the fifth fetal month and the time of its origination was in the stage of the "Haarbulbuszapfen." Namely, our findings were almost in accord with Diem's, Backmund's and.Morise's observations.

About the cause of the formation of the glandular lumen: Kölliker (1850) reported that the cause of the formation of the glandular lumen was due to formation of space between the cells which composed the primordia of the sweat glands and due to destruction of the cells. On the apocrine sweat glands, Tawara (1932) and Mogi (1938) insisted, that the formation of the glandular lumen arose in the space between the axial cells at the apex of the primordia of the sweat glands. On the eccrine sweat glands, Backmund (1904); Bonnet (1929), Diem (1907); Wimpfheimer (1907): and Pinkus (1910) considered the cause of the formation of the glandular lumen to be due to the destruction of the cells.

Moreover, Wimpfheimer (1907) and Pinkus (1910) insisted that the 
secretion accumulated among the cells caused the enlargement of the space.

Ueda (1939) reported that in the portion, which was pressed by the flexion at the transitional region between the apex and the median portion of the sweat glands, the union among the axial cells was broken, so that the space between the cells was formed and enlarged by the pressure of the fluid accumulated in the small space.

Kan (1941) reported on the formation of the glandular lumen in the apocrine and the eccrine sweat glands on the axillary sweat glands. Namely, the space between the cells was caused by the axial cells near the apex of the sweat glands parting from each other, and these cells developed and formed in line radiately so that the glandular lumen was formed. Therefore, by the destruction of the axial cells and by the secretory function of the primordia, it is impossible for fluid to accumulate in the space between the cells.

In our investigation, the nucleus in the cells at the apical portion of the primordia of the sweat glands in the period of the formation of the glandular lumen has a strong stainability for hematoxylin and in some nuclei the mitotic figures are recognizable. Most of the glandular lumen was recognizable as a fissure between the cells which arrange themselves parallel to the longitudinal axis in the primordia. Moreover, from the fact that the cells in the central portion of the apical ampulla of the primordial sweat glands have a more intensive stainability for hematoxylin than those in the peripheral portion, the formation of the glandular lumen is considered to be caused by the separation between the cells or by the necrosis of the centric cells at the apical region of the primordia. Besides another cause of the formation of the glandular lumen is probably expected.

However, it can not be considered that the glandular lumen is formed by the pressure of the accumulated fluid; because the figures of the secretion by the primordia of the sweat glands were not visible.

On the formation of the glomerulus in the glandular corpus: On the apocrine sweat glands, Contino (1907) on the ciliary glands of the $22.5 \mathrm{~cm}$ embryo, Tawara (1932) on the ciliary glands of the twenty-eight-week-old fetus, Iwata (1933) on the ceruminous glands in the thirty-two-week-old embryo, and Mogi (1938) on the nasal vestibular glands of the human embryo in the seventh fetal month found the formation of the glomerulus.

But in our cattle fetus, the glomerular formation was not visible even in the eighth fetal month.

On the opening of the glandular lumen to its entire length: Kölliker (1850) and Wimpfheimer (1907) believed that the ductular lumen arose without any 
relation to the glandular lumen in the glandular corpus, but ductular lumen would open to its whole length. Tawara (1932) on the apocrine sweat glands, reported, that the glandular lumen arose in the tubule at first, then it was formed gradually. Kan (1941) reported that the tubule of the sweat gland gradually was formed as the continuous tubule with the glandular Iumen which was given to rise in the glandular corpus.

In our cattle embryos, on the sections, cut transversally, in the parts of the fetal bodies in the beginning of the fifth fetal month and in the middle of the sixth fetal month, the glandular lumen was formed, but the formation of the excretory tubular lumen was not yet recognized. It was not until the beginning of the eighth fetal month that both the glandular lumen and the excretory tubular lumen were formed. On the sections of the cuticle cut longitudinally, though the tubular lumen of the duct is not clear, at first, an elliptic glandular shape is formed, then the tubular lumen begins to be recognizable among the cell groups on the transitional region from the glandular corpus to the excretory tubular portion and the formation of the tubular lumen in the duct follows.

On the histogenesis of the sweat glands: In the early developmental period the cells in the glandular corpus are composed of the undifferentiated epithelial cells as well as those in the excretory tubular portion. When the formation of the glandular lumen begins in the sixth month of the fetal iffe, several layers of the cells arrange themselves around the glandular lumen. In the external layers one or sometimes two lines of the flat spindle-formed cells are arranged and the nucleus of these cells is elliptic or spindle-shaped and is abundant in chromatin as compared with that of the cells in the internal layers several cell-layers arrange themselves irregularly, and the nucleus is oval and there are two kinds of cells, one of which is abundant in chromatin and the other is poor. Inside the glandular lumen the cells which have a very weak staining nucleus are recognizable.

In the period of the completion of the glandular lumen the glandular corpus is surrounded with two cell-layers, an internal and external layer. The cells in the external layer show about the same findings as the external layers mentioned above. The cells in the inner layer become one line and they are composed of the flat or short cuboidal cells. The nucleus is elliptic and locates in the central portion of the cells. Moreover, it is abundant in chromatin and on the cattle embryo the cells generally show a fiat figure.

Kan (1941) insisted that on the axillary glands where a small lumen is being formed in the glandular corpus, two differentiated epithelial cell layers 
which surrounded the small lumen, were recognizable and the cells of the inner layer of the two were increased with mitosis.

However, in our findings, the nucleus of the cells of the inner layer was more abundant in chromatin in the early period of the formation of the glandular lumen than in the later period, but no figures of the mitosis were visible. On the cytoplasm of the glandular epithelial cells in the glandular corpus in the six to eight month-old embryo, the free side faced the glandular lumen and showed a cord-like figure which stained linearly with eosin. This region was named corneous zone by Ueda (1939), "Kutikularsaum" by Kölliker (1879) and Kan (1941), and was in accord with the "Crusta" named by Brinkmann (1909), Hoepke (1927) and Schaffer (1924). Narita (1955), too, recognized the similar figures of the cytoplasm on the primordia of the ceruminous glands in the six month-old human embryo. Osogoe (1951) on the ceruminous glands recognized them. Minamitani (1941) recognized them on the axillary sweat glands and these were in accord with the region named "crusta."

On the other hand, in our cattle embryos the zone of the cord-like cytoplasm was thinner than that in the reports mentioned above.

The "Kittleiste" between the so-called crusta of a glandular epithelial celllayer was not recognized clearly. Kan (1941) reported that on the axillary glands of the human embryo in the eighth fetal month, the intercellularsecretory tubule was recognizable but it faded out in the time when the apocrine sweat glands began to secrete (eight years-old). Kolmer (1927), too, found the existing of the intercellular secretory tubule. While, Narita (1955) described that the intercellular secretory tubule on the ceruminous glands of the four to ten monthis-old human embryos was not recognizable, and also Osogoe (1951) said, so.

In our cattle embryos the intercellular secretory tubule was not recognizable in the findings until the eighth fetal month.

About the secretory function of the primordia of the apocrine sweat gland: About this matter, Kan (1941) on the embryo in the eighth fetal month, Narita (1955) in the nine to ten months-old-embryo recognized the figures that the apccrine sweat glands secreted.

However, in our cattle embryos the figures of the apocrine sweat glandular secretion "were not recognizable until the eighth fetal month.

In parallel with the differentiation of the internal cells in the glandular corpus of the primordia of the sweat glands into the glandular cells, the external cells are considered to develop into the epithelial smooth muscle. Narita (1955) said that the cells of the external layer developed on the ceruminous 
glands of the human embryo in the sixth fetal month.

In our cattle embryos the cells which arranged themselves coarsely were. recognized along the longer axis in the glandular corpus of the six months-old embryo and their form were flat. The nucleus was rod-like shaped.

Narita (1955) also reported, that the gland which formed the glomerule in the six months-old embryo gave rise to myofibrils and that this suggested the beginning of the function in the myoepithelial cells. Kan (1941) asserted, that in the eight months-old fetus some cellular corpus projected into the basal region of the internal cell-layer and in the third year they changed into the smooth muscle in the form of filaments which ran parallel to the longitudinal axis of the tubular lumen. In the cytoplasm the myofibrils were recognized.

In our cattle embryos, in the eighth fetal month the arrangement of the cells in the external layer is still sparse along the longer axis of the glandular: corpus. The arrangement in the form of filaments is not clearly visible and no myofibrils are found in the cytoplasm. Moreover, no figures that the cytoplasm of the cells in the external layer projects into the basal region of the intermal cells of the layer, are found.

The arrangement of the cells in the excretory tubule of the five months-old fetus is still irregular. The cells in the utmost external layer show the flat form but others are short columnar. On the embryos ranging from the middle of the sixth fetal month to the eighth, the excretory tubule is composed of two clear cell layers, the inner one of which consists of the short columnar cells and their nucleus is elliptic, being abundant in chromatin. On the freesurface facing the ductular lumen of the cytoplasm, some thinner layers which stain linearly with eosin are visible. Kan (1941) reported on the structure like the cuticular border that this structure was already recognizable in the tubule at the end of the fetal life but the true cuticular border appeared since eighth month after birth. Brinkmann (1909) reported that it appeared in the definite secretory period of the apocrine sweat glands.

In our, cattle embryos the cuticular border is recognizable as, the linear structure from the beginning period of the formation of the tubular lumen and it appears to be thicker than that in the glandular corpus. But it is considered that owing to the narrowness of the tubular lumen of the excretory tubular portion as compared with the glandular lumen of the glandular corpus, the cuticular border appeared to be thicker.

On the basement membrane: Kölliker (1850) stated, that the primordia of the sweat glands in the human embryo were covered with a connective tissue tunic. Backmund (1904) reported that the primordia of the sweat glands. 
in the cat embryos were surrounded by thin connective tissue membrane. Kan (1941) reported, that the primordia of both sweat glands apocrine and eccrine in the axillary region of the seven months-old embryo were enclosed by a thin structure-less basic membrane under hematoxylin-eosin staining.

In our materials, under the hematoxylin-eosin staining the structure to be considered as the basic membrane was not recognizable. However, some portions out of the zonal regions which were not stained with eosin and were recognizable around the glandular corpus, appeared to be in accord with the thin structureless basal membrane mentioned above.

About the transitional region: Kan (1941) reported, that the cuboidal cells in the internal layer of the excretory tubular epithelium gradually became higher and the cuticular border faded out passing over to the columnar cells of the glandular duct. Ito and Enjo (1949) described that on the anterior side of the thigh and posterior side of the forearm in human adults, and on the skins of men, who possessed the smell of the armpit and who did not possess it, the transitional regions, which had a specific epithelium corresponding with the neck-portion (strait and medial part) on the excretory ducts of the usual glands, were recognizable. Namely, their thickness and width lay between the glandular lumen's and excretory tubule's and their length was short. The epithelium consisted of two layers and on the apocrine sweat glands secreting figures failed.

In the sweat glands of the cattle embryos, regions where stainability in the nucleaus was strong for hematoxylin, and the tubular lumen was very narrow and short in the developmental process, were recognized between the excretory tubule and the glandular corpus. But the epithelium did not always consists of two layers as mentioned by Ito and Enjo. Not any secretory figures were found. Accordingly it is hard to say that the figures found in our material correspond with the transitional region which Ito and Enjo found in human adults. However, from the facts, that the nucleus had an intensive stainability and the cells composing several layers massed together, we can see that these regions are not only formal transitional regions from the glandular corpus to the excretory tubule, but there also seem to be some regions related to the growth of the primordia of the sweat glands.

\section{SUMMARY}

1. We have studied on the sweat glands on the six parts of the cattle embryo, from the developmental and histogenetic points of view; namely the fore-head, breast, abdomen, hypogastrium, back and sole (hairly portion) of the cattle fetus 
from the beginning of the third fetal month to the end of the eighth.

2. The sweat glands on the cattle embryos secondarily arise from the hair bases and belong to the apocrine sweat glands. Moreover they are "monoptische Drüsen."

3. The primordia of the sweat glands originate in the middle of the fourth fetal month for the first time and it is in correspondence to the stage of the "Haarzapfen" in the hair bases.

4. The regions where the sweat glands spring up for the first time are forehead and sole. The abdominal part follows next.

5. As compared with the sole and the forehead both of which give rise to the first primordia of the sweat glands, a few best developed primordia of the sweat glands occur on the forehead, while on the sole many primordia which are later in development than those on the forehead are perceptible.

6. One hair base gives rise to only one primordia of the sweat gland in any region of the body. That is to say, one hair base does not give rise to two or more primordia of the sweat glands in any parts of the body.

7. The papillary primordia of the sweat glands are still recognizable on the breast and hypogastrium of the cattle embryo in the beginning of the fifth fetal month, but not recognizable after then. The clavate primordia of the sweat glands are numerously recognizable in every part of the fetal body in the middle of the sixth fetal month but none in the beginning of the seventh fetal month.

8. The bending at the apex of the primordia of the sweat glands was recognized for the first time on the sole of the embryo in the beginning of the fifth fetal month. In about the similar period it was noticeable on the forehead and hypogastrium.

With regard to the cause of the bending at the apex of the primordia of the sweat glands, it is necessary that the leading relation with the bending of the apex and the hair bases, and a tendency to bend in the primordia of the sweat gland itself are take into consideration in addition to the newly originated blood vessels and to the rapid development of the epidermis having the relations with the bending.

9. The initial region where the glandular lumen in the sweat glandular corpus is formed, is the transitional region from the apical ampulla of the sweat gland to the excretory tubular portion, and this is recognizable on the primordial sweat glands which belong on the forehead of the embryo in the beginning of the fifth fetal month to the hair bases in the stage of the "Bulbuszapfen."

The tubular lumen of the excretory tubule was at first recognized on the forehead of the embryo in the beginning of the eighth fetal month. 
As for the causes of the formation of the glandular and tubular lumen, pressure by accumulated liquid, necrosis of the axial cells in the ampulla mentioned by many scientists were found.

10. No formations of the glomerulus on the glandular corpus were recognizable in the embryo by the end of the eighth fetal month.

11. As for the orifice of the sweat glands into the hair follicles, most of the sweat glands opened their orifice into the hair follicles near the epidermis sometimes some of sweat glands opened their orifice onto the transitional region, between th hair follicle and the epidermis.

12. No sweat glands opened their orifice onto the epidermis without any relation to the hair follicles. However, from the beginning of the origin some primordia of the sweat glands arose from the transitional region between the hair bases and the epidermis. In regard to the movement of the orifice onto the epidermis, no evidences were recognizable.

13. Degradations or vestiges of the primordia of the sweat glands were not noticed.

14. The glandular corpus at the beginning of the formation of the glandular lumen showed an irregular formed lumen surrounded by several layers of the cells but, when the glandular lumen was completed, it was recognizable as an elliptic or S-formed lumen which was surrounded with a flat epithelial cell-layer and fiat cells (= undifferentiated myoepithelial cells) which surrounded the exterior of the epithelial cells.

The excretory tubular portions consisted of two cell-layers, the inner one of which composed short columnar cells, the outer one was recognizable as flat cells. In both the glandular epithelial cells and the inner cells of the excretory tubular portion, the cytoplasms faced the glandular or tubular lumen stained deeply zonally with eosin.

We should like to express our sincere thanks to Prof. Dr. T. Taniguchi who gave us his kind guidance and criticism. Also, we are gratefully indebted to Dr. A. Sugawa and S. Homma in the National Institute of Animal Health in Tokyo and to Dr. M. Imai, the lecturer at the University of Agriculture and Industry in Tokyo, for their cordial help in collecting the cattle embryos.

\section{REFERENCES}

1. Akagi, T.: Entwicklungsgeschitliche Untersuchung der Haare und der Hautdrüsen am Gesicht der menschlichen Embryonen. Japanische Zeitschrift für Anatomie. 13: 598-666, 1939. (Japanisch)

2. Albrecht, R.: Handbuch der Tierärztl. Geburtshilfe. 5 Aufl. 82-93, 1914. 
3. Alzheimer, W.: Über die Ohrenschmalzdrüsen. Verhandl. d. Würzburger physik. med. Geschell. neue Folge. 22: 128-143, 1888.

4. Alverdes, K.: Die apokrinen Drüsen im Vestibulum nasi, Z. f. mikr. anat. Forsch. 28: 183-201, 1932.

5. Alverdes, K.: Die Entwicklung der Glandulae vestibulares nasi des Menschen. Z. f. mikr. anat. Forsch. 35: 76-97, 1934.

6. Asdel, S. A.: Patterns of Mammalian Reproduction. Ithaca, New York. Comstock Pub. Co. pp. 96, 1946.

7. Aurell, G.: Studien über den Bau und die Entwicklung der Schweissdrüsen der menschlichen Fusssohle. Z. f. mikr, anat. Forsch. 44: 56-72, 1938.

8. Blaschko, A.: Beiträge zur Anatomie der Oberhaut. Arch. f. mikr. Anat. 30: 186-212, 1887.

9. Backmund, K.: Entwicklung der Haare und Schweissdrüsen der Katze. Anat. Hefte, 26: 17-39, 1904.

10. Becker, J.: Über Haut und Schweissdrüsen bei Foeten und Neugeborenen. Z. Kinderheilk. 30: 192-216, 1921.

11. Bergmann, R.: Arch. Tierheilk. 47: 292-315, 1921.

12. Bonnet, R.: Lehrbuch der Entwicklungsgeschichte. S. 312, 1929.

13. Brinkmann, A.: Über das Vorkommen von Hautdrüsenorganen bei den anthropomorphen Affen. Anat. Anz. 34: 232-251, 1909.

14. Brinkmann, A.: Die Hautdrüsen der Säugetiere. Ergeb. d. Anat. u. Entwicklungsgeschichte. 20: 162-193, 1911.

15. de Bruin: Handbuch der Tierärztl. Chirurgie und Geburtshilfe (Bayer-Frohner) Teil: Geburtshilfe beim Rind 328, 1910.

16. Clausen, A. und Alexanderson, B.: Beiträge zur Kenntnis der Entwicklung der Schweissdrüsen des Menschen. Z. f. mikr. anat. Forsch. 30: 292- 316, 1932.

17. Contino, A.: Über Bau und Entwicklung des Lidrandes beim Menschen. v. Graefes Arch. f. Ophthalm. 66: 132-141, 1907.

18. Diem, F.: Beiträge zur Entwicklung der Schweissdrüsen an der behaarten Haut der Säugetiere. Anat. Hefte, 34: 38-56, 1907.

19. De Meijere: Über die Haare der Säugetiere. Morph. Jahrb. 21: 318-349, 1907.

20. Eggeling, H.: Über ein wichtiges Stadium in der Entwicklung der mensehlichen Milchdrüse. Anat. Anz. 14: 186-218, 1904.

21. Ellenberger, W.: Handbuch der vergleichenden mikroskopischen Anatomie der Haustiere Bd. 3. SS. 512-563, 1911.

22. Fischel, A.: Lehrbuch der Entwicklung des Menschen. Verlag von Julius Springer, Wien und Berlin, 1931.

23. Greefberg, Wilh: Die Haut und deren Drüsen in ihrer Entwicklung. Mitteil. aus d. embryol. Inst. d. Universität in Wien. 2: 138-162, 1883.

24. Gurlt, E. F.: Vergleichende Untersuchungen über die Haut des Menschen und der Haussäugetiere, besonders in Beziehung auf der Absonderungsorgane des Hauttalges und des Schweisses. Müllers Arch. 15: 263-291, 1835.

25. Hertwig, O.: Lehrbuch der Entwicklungsgeschichte des Menschen und der Wirbeltiere. Verlag von Gustav Fischer, Berlin, 1910. 
26. Hoepke, H.: Die Haut: Handbuch der mikroskopischen Anatomie des Menschen (W.v. Möllendorff). 1/3: 328-367, 1927.

27. Hammond, J.: Reproduction in the cow. Cambridge Univ. Press., 1927.

28. Ito, T. and Enjo, S.: Cytological study on the excretory tubule of the sweat gland. I. Study on the transitional region between the glandular tubule and the excretory tubule. Science in the living body. 2: 69-73, 1949. (Japanese)

29. Iwata, R.: A developmental study on the gl. ceruminosa of the human embryos. Kaibogaku Z. 5: S. 1063-1077, 1933. (Japanese)

30. Kan, M.: Histological and histogenetic investigations on the axillary sweat glands in Japanese. Nagoya med. Z. 54. 366-392, 1941. (Japanese)

31. Kölliker, A.: Zur Entwicklungsgeschichte der äusseren Haut. Z. Wiss. Zool. Bd. 2 1850.

32. Kislovsky, D. A. and Larchin, B. A.: The periods of embryonic growth in cattle. J. of Agr. Sci. 21: 206-219, 1931.

33. Krause, W.: Entwicklung der Haut und ihre Nebenorgane. Hab. d. vergl. u. exper, Entwicklungslehre 2: 253-349, 1906.

34. Maurer, F.: Hautsinnesorgane, Feder u. Haaranlage u. deren gegenseitige Beziehungen, ein Beitrag zur Phylogenie der Säugetierehaare. Morph. Jahrb. 18: 717, 1892.

35. Mogi, E.: Beiträge zur Entwicklung der apokrinen Schweissdrüssen im Vestibulum nasi bei den japanischen Foeten. Folia anat. Jap. 16: 218-242, 1938.

36. Morise, M.: A supplement to the findings on the development of the skin and its appendages in mammals. Niigata Univ. Med. Anat. Jour. 33: 87-130, 1954. (Japanese)

37. Morioka, U.: Report on the development of the axillary sweat glands in the human embryos. Okayama med. jour. 48: 150-166, 1935. (Japanese)

38. Nagai, S.: Study on the development of the sweat glands and hairs in the upper arms in Japanese. Kaibogaku Z. 9: 755-848, 1936. (Japanese)

39. Narita, Y.: Cytological study on the ceruminous glands in human embryo. Arch. hist. jap. 7: 68-83, 1954. (Japanese)

40. Maneely, R. B.: Note on the aging of bovine embryos. The veterinary Record. 64: 518-536, 1952.

41. Pinkus, F.: Entwicklungsgeschichte der Haut. Keibel-Mall's Handbuch der Entwicklungsgeschichte des Menschen. Bd. 1 212-328, Verlag von Hirzel, Leipzig., 1910.

42. Pinkus, F.: Anatomie der Haut. Jadasson's Handbuch der Haut u. Geschlechtskrankheiten 1: 77-321, 1927.

43. Schaffer, J.: Zur Einteilung der Hautdrüsen. Anat. Anz. 57, 1924.

44. Schiefferdecker, P.: Die Hautdrüsen und der Säugetiere. Zoologica 27: 1-22, 1922.

45. Steiner, K.: Über die Entwicklung der grossen Schweissdrüsen beim Menschen. Z. f. Anat. u. Entwicklungsg. 78: 83-97, 1926.

46. Stöhr, Ph.: Entwicklungsgeschichte d. menschlichen Wollhaares. Anat. Hefte 23: 1-59, 1903.

47. Tawara, T.: On the development of "Moll'sche Drüse" in the embryos. Kaibogaku 
Z. 5: 743, 1932. (Japanese)

48. Ueda, M.: Study on the development of the skin and its appendages in Japanese. Nagasaki med. Jour. 17: 68-96, 1939. (Japanese)

49. Sato, S.: Obstetrics of the domestic animals. Yokendo, Tokyo. pp. 12-98, 1932.

50. Wimpfheimer, C.: Zur Entwicklung der Schweissdrüsen der behaarten Haut. Anat. Hefte. 34: 118-142, 1907. 
Specimen Number 20 Middle of the fourth fetal month

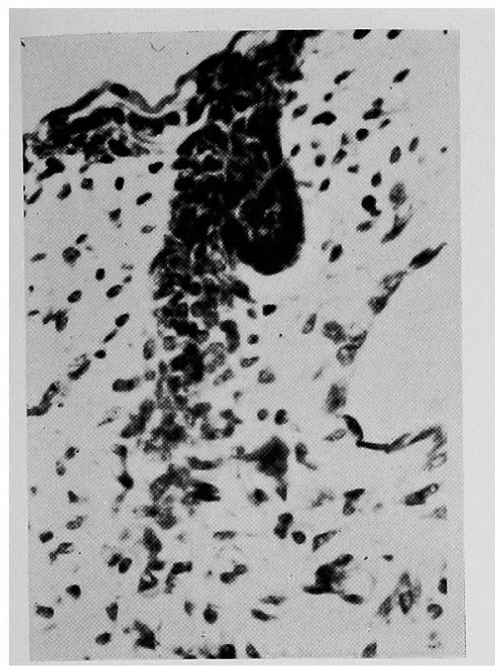

Fig. 1 Forehead

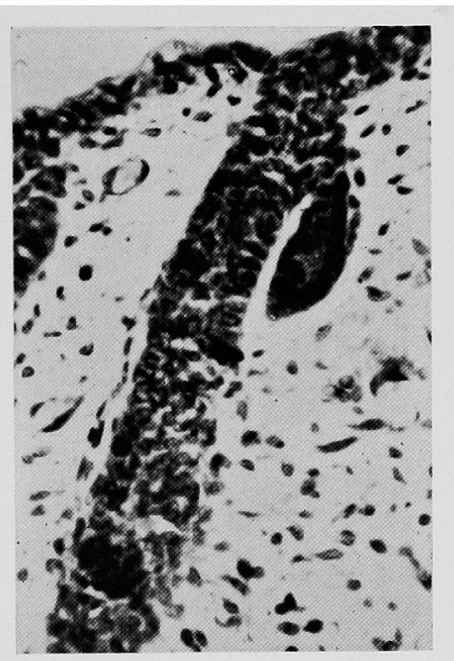

Fig. 2 Forehead

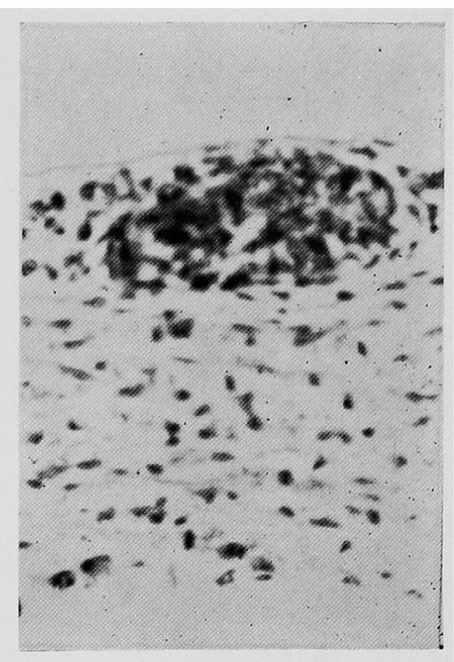

Fig. 3 Breast

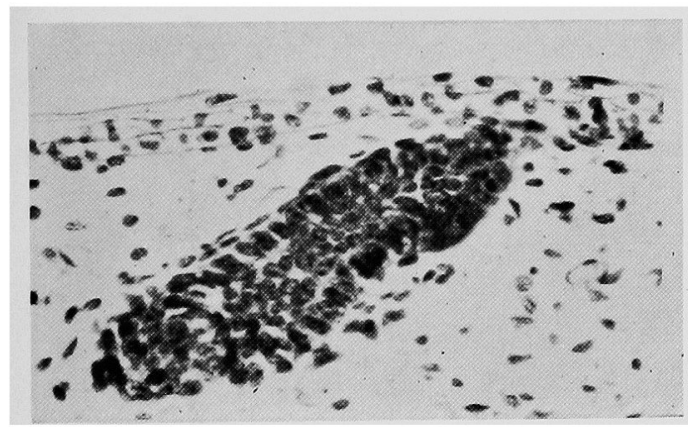

Fig. 4 Abdomen

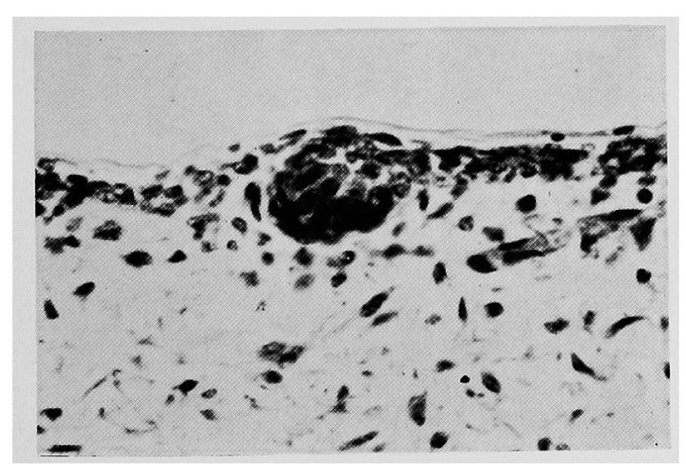

Fig. 6 Back

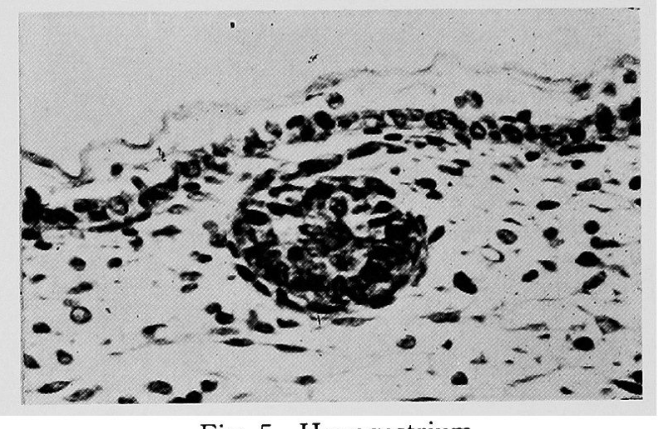

Fig. 5 Hypogastrium

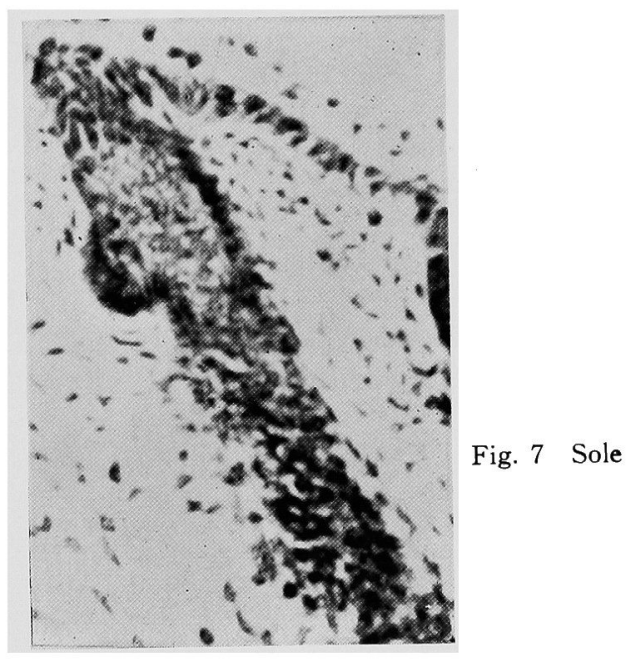

K. YASUDA 
Specimen Number 31 Beginning of the fifth fetal month

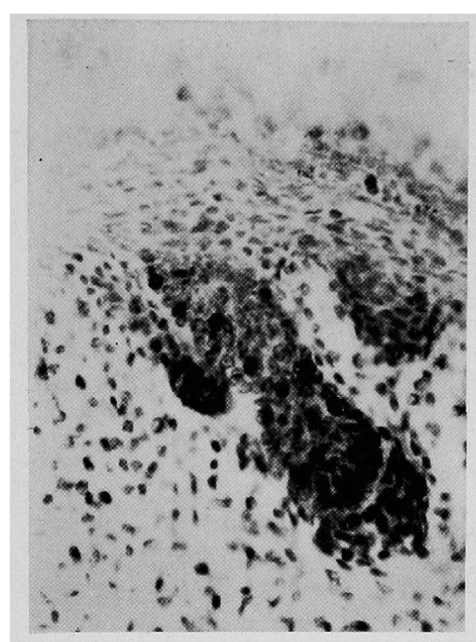

Fig. 8 Forehead

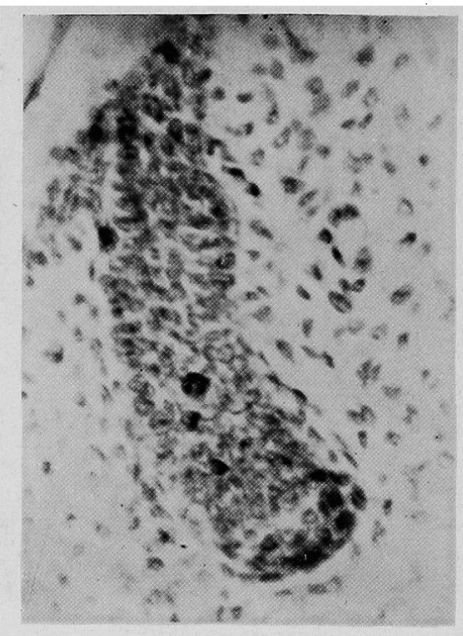

Fig. 9 Breast

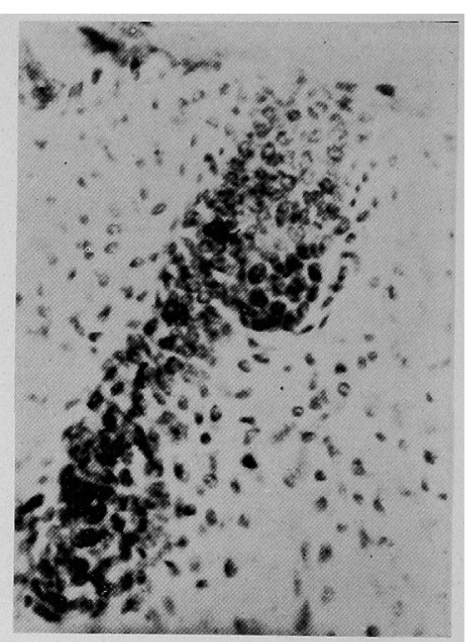

Fig. 10 Abdomen

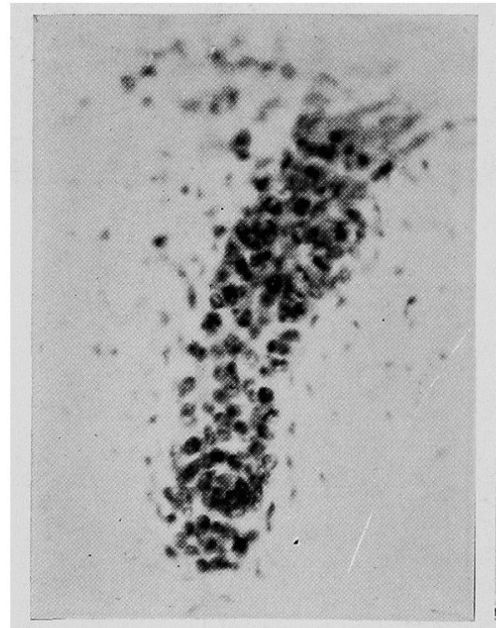

Fig. 11 Hypogastrium

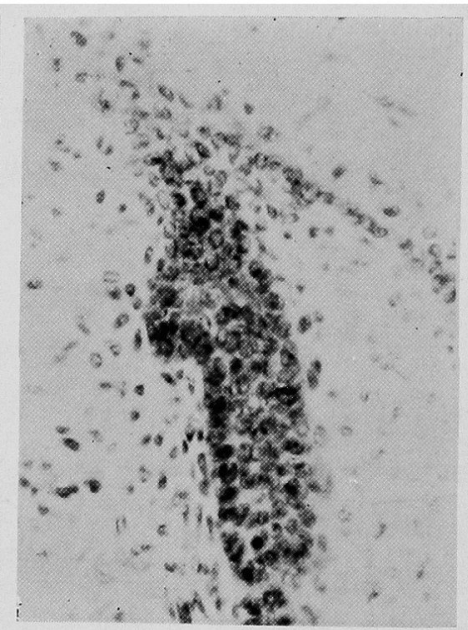

Fig. 12 Back

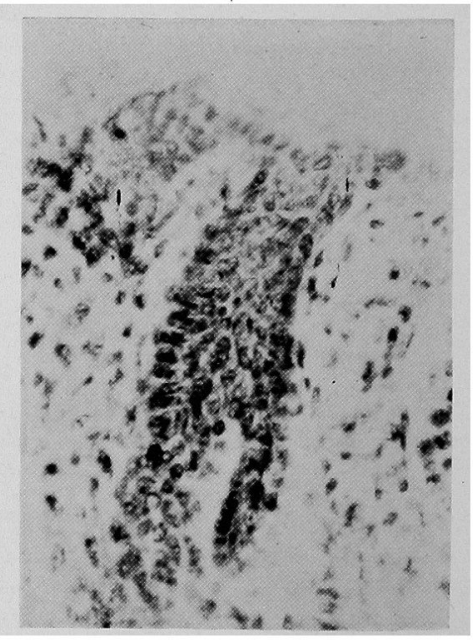

Fig. 13 Sole 
Specimen Number 32 Middle of the sixth fetal month

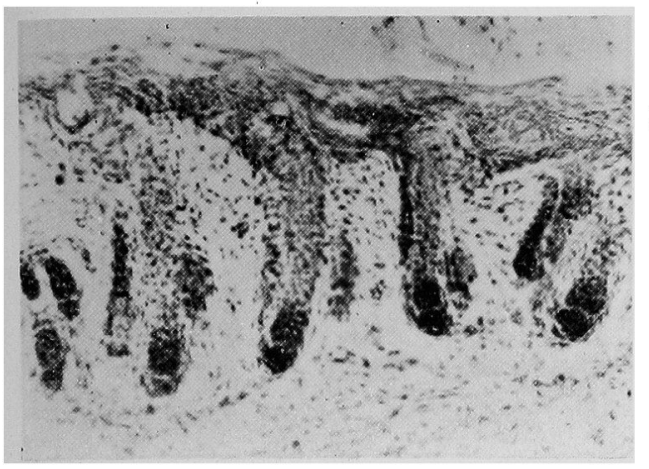

Fig. 14 Forehead

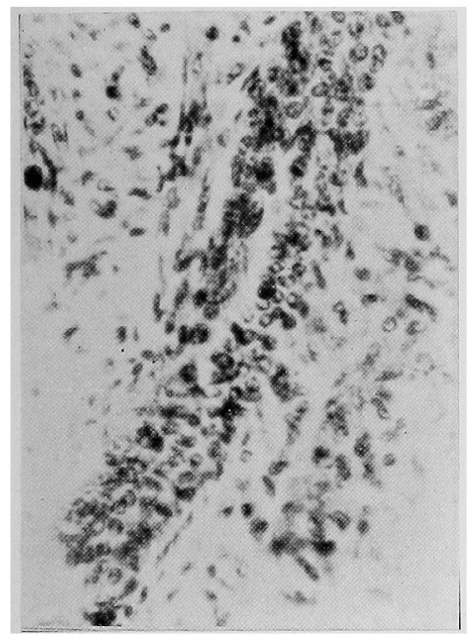

Fig. 16 Abdomen

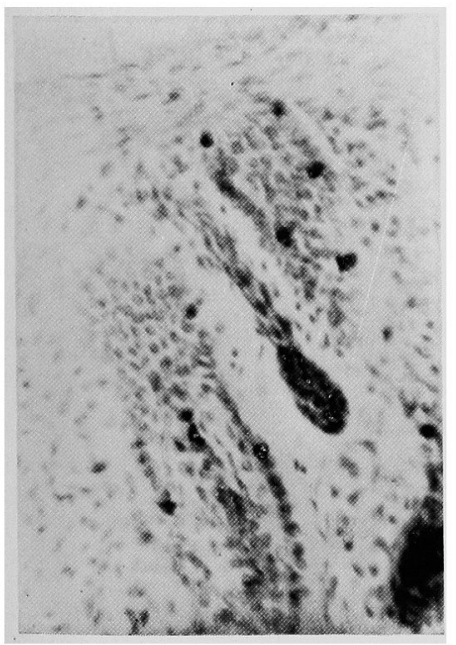

Fig. 19 Sole

Fig. 20 Sole

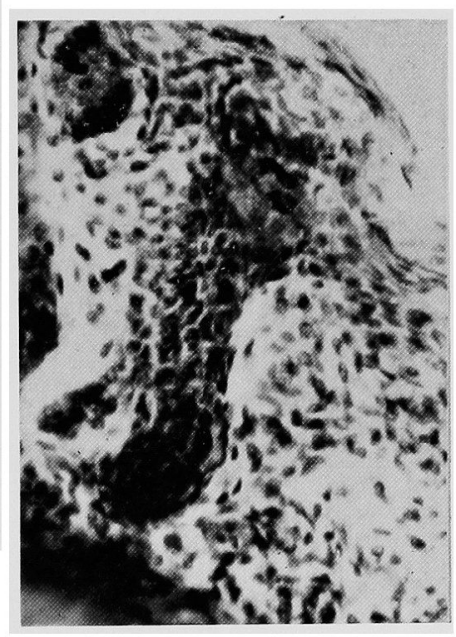

Fig. 17 Hypogastrium
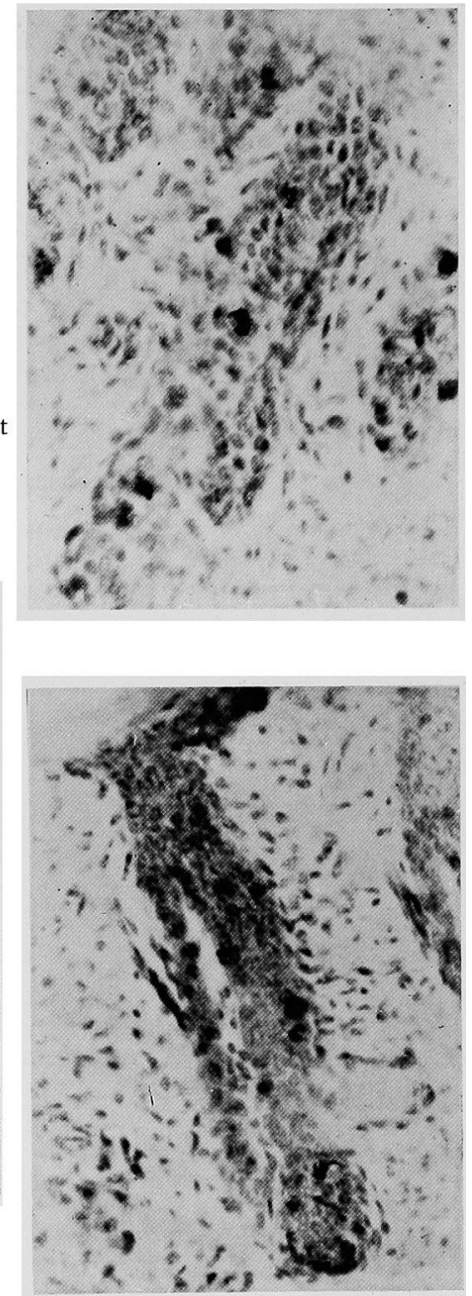

Fig. 18 Back

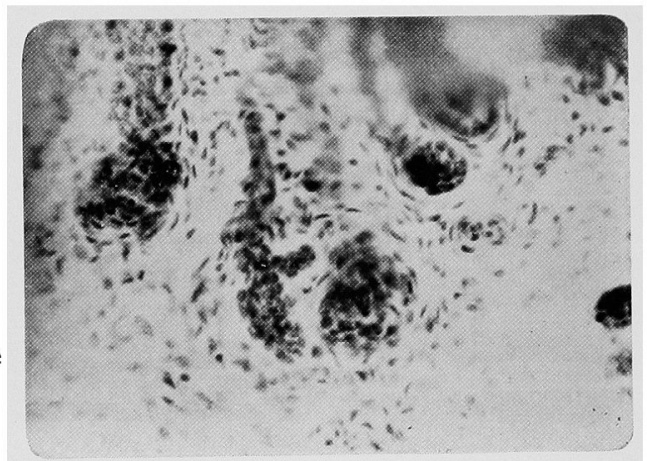




\section{Specimen Number 40 Beginning of the seventh fetal month}

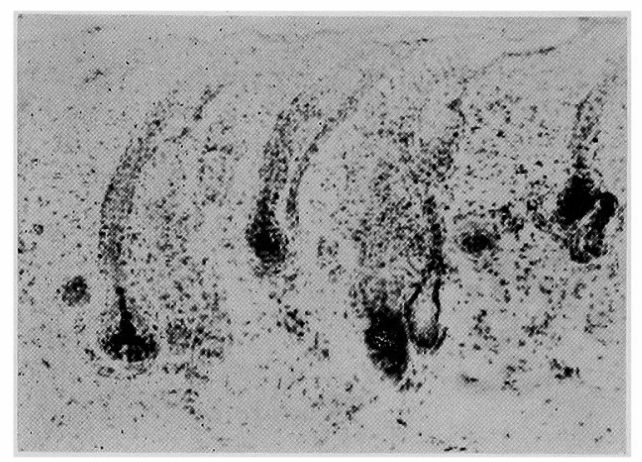

Fig. 21 Forehead

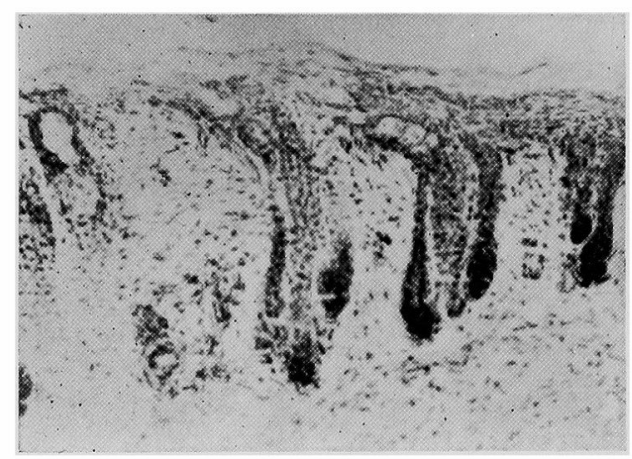

Fig. 23 Abdomen

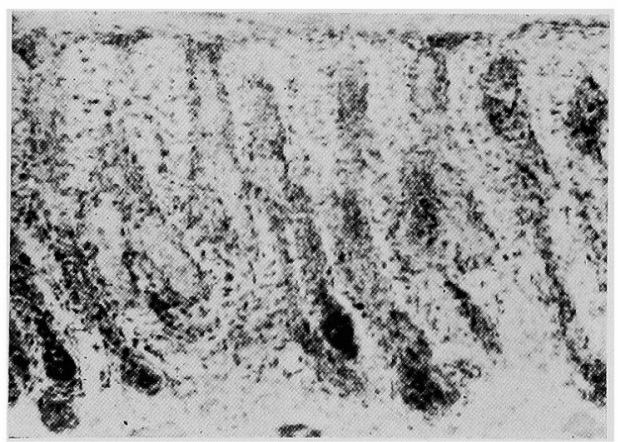

Fig. 25 Back

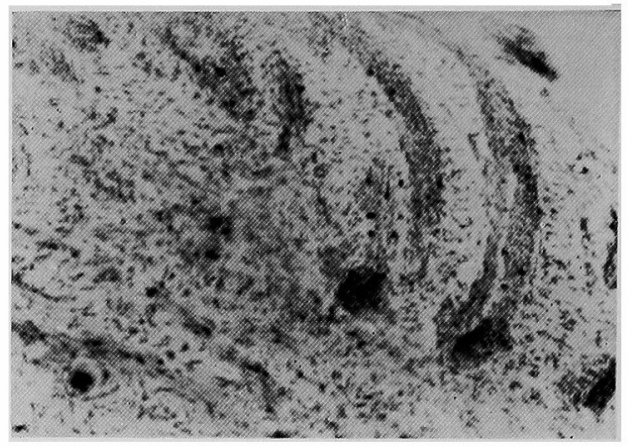

Fig. 22 Breast

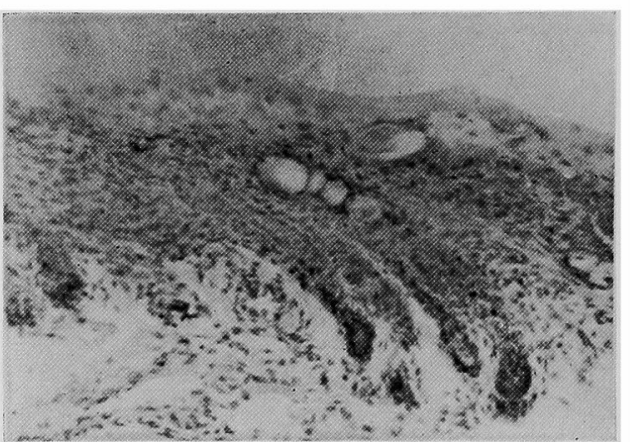

Fig. 24 Hypogastrium

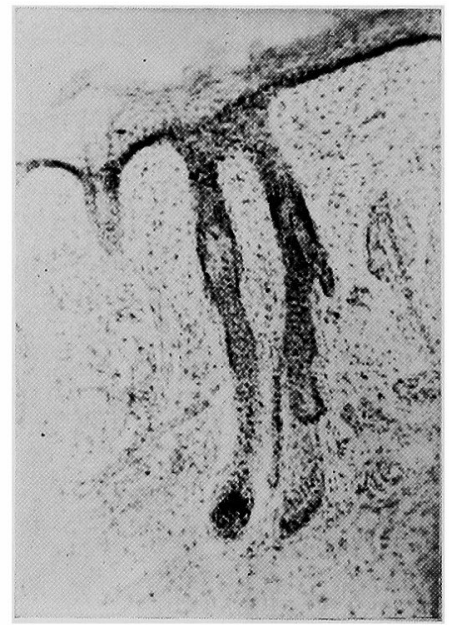

Fig. 26 Sole 
Specimen Number 34 End of the seventh fetal month

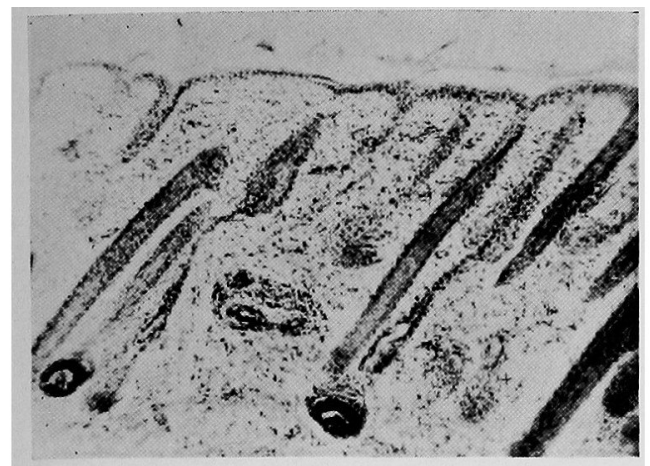

Fig. 27 Forehead

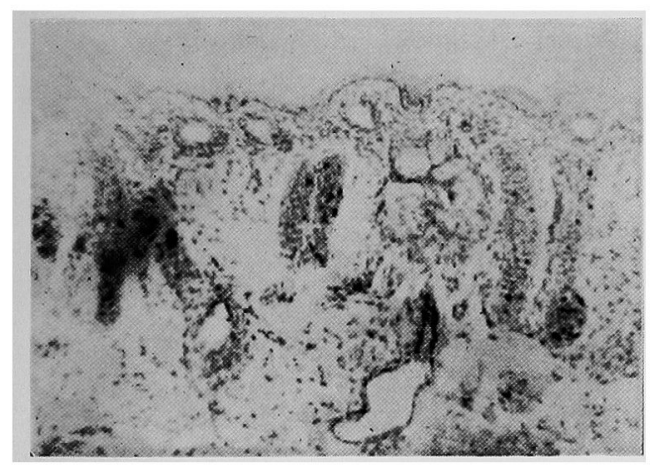

Fig. 29 Abdomen

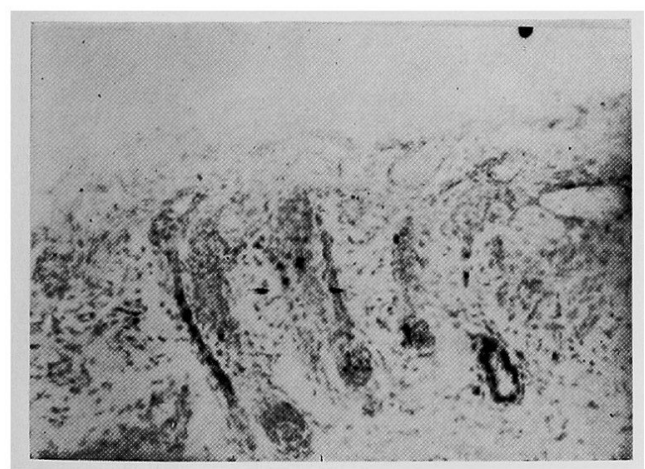

Fig. 31 Back

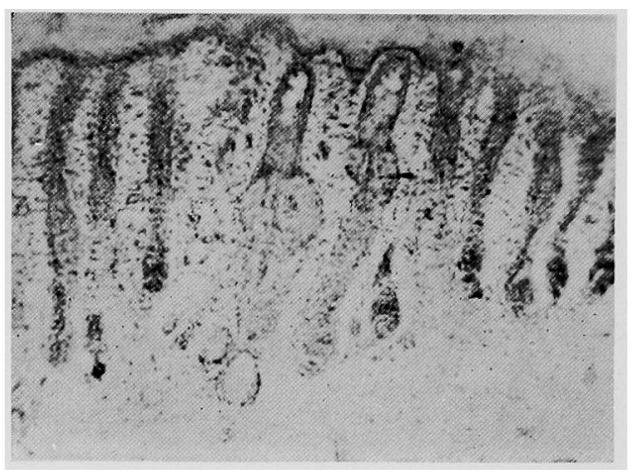

Fig. 28 Breast

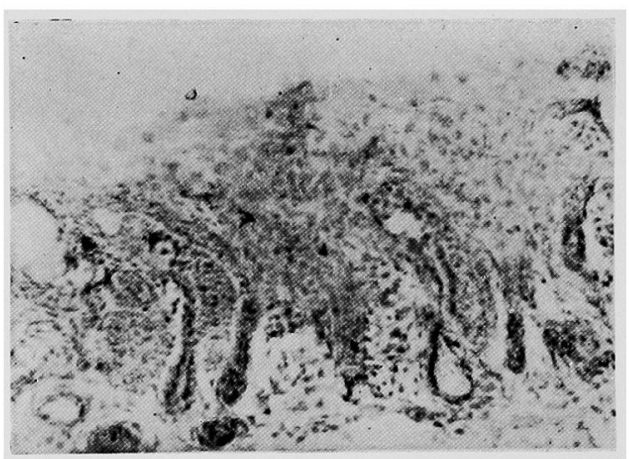

Fig. 30 Hypogastrium

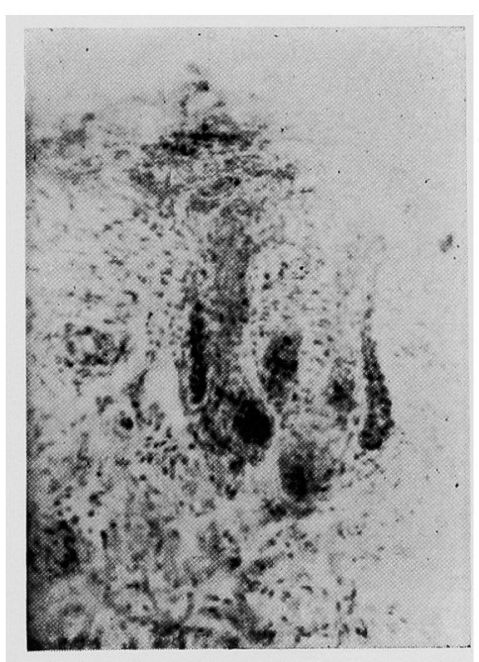

Fig. 32 Sole

K. YASUDA 
Specimen Number 39 Beginning of the eighth fetal month

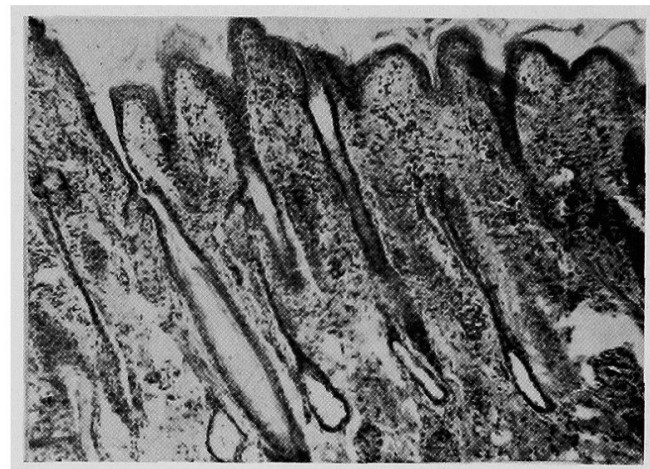

Fig. 33 Forehead

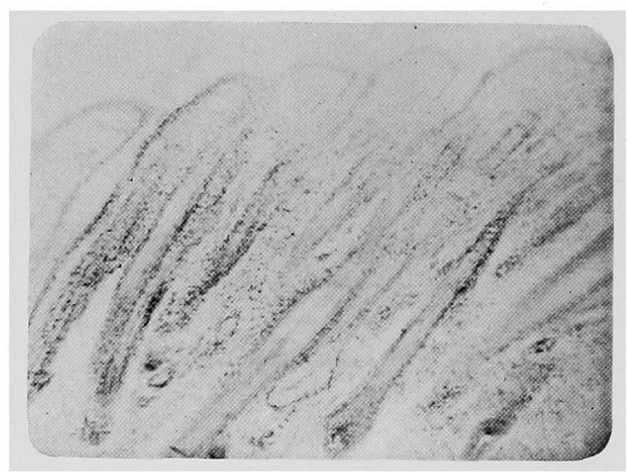

Fig. 35 Abdomen

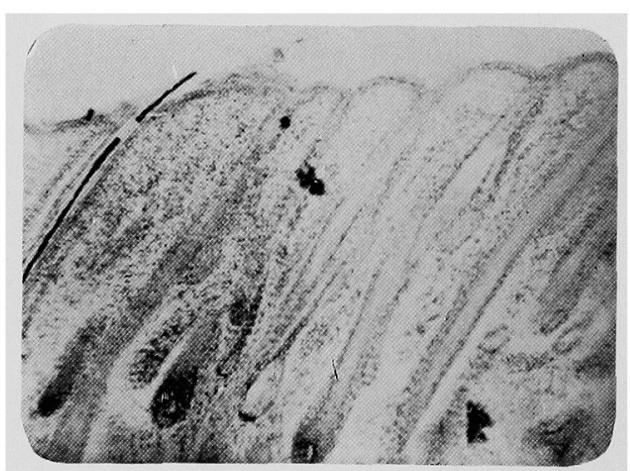

Fig. 37 Back

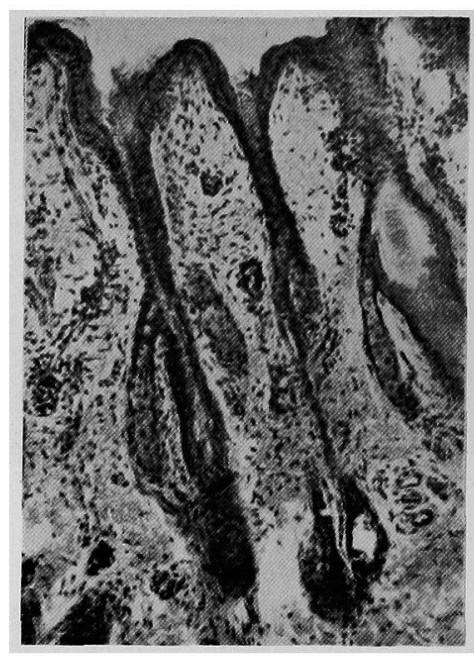

Fig. 34 Breast

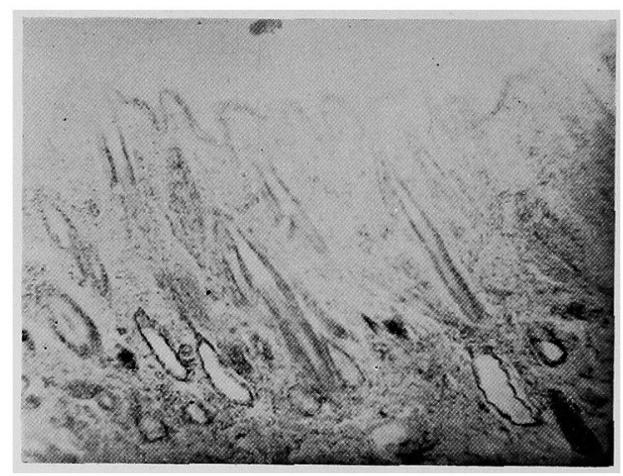

Fig. 36 Hypogastrium

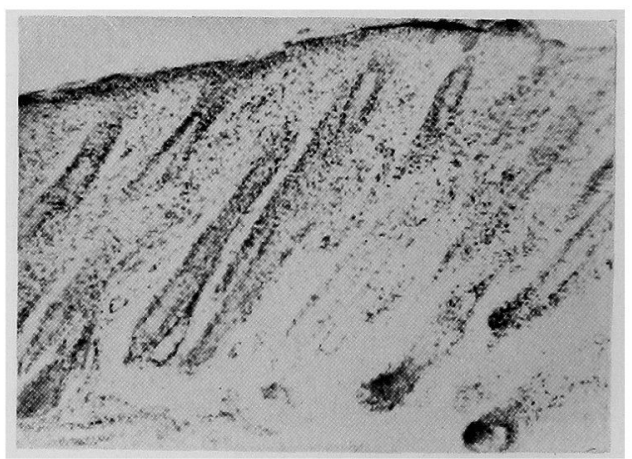

Fig. 38 Sole 
Specimen Number 37 End of the eighth fetal month

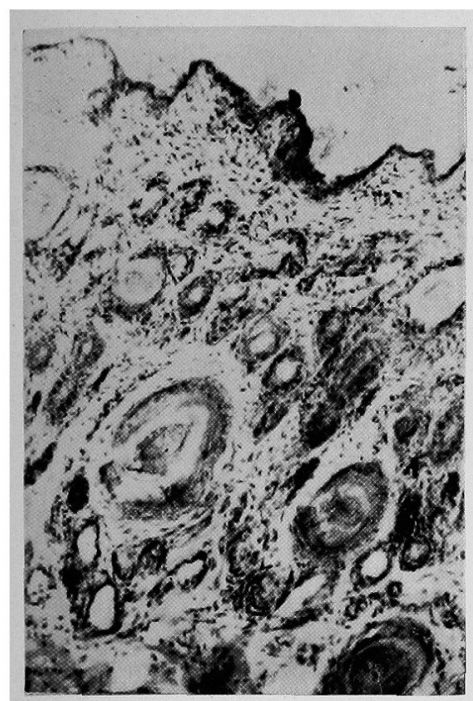

Fig. 39 Forehead

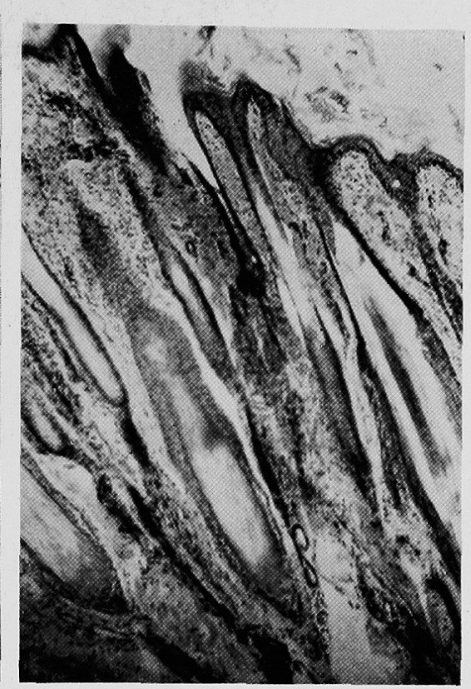

Fig. 40 Breast

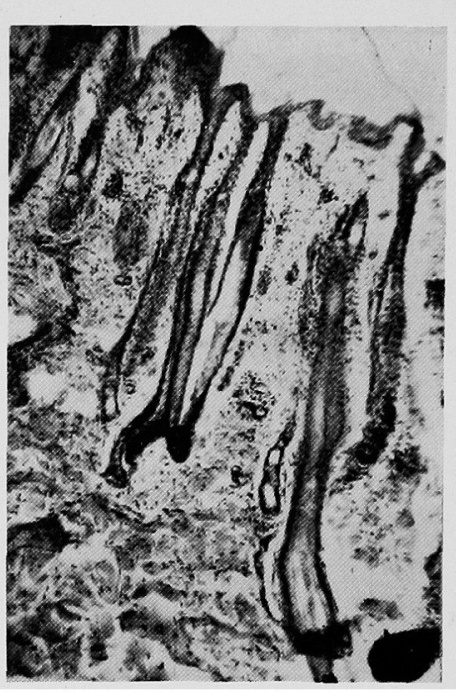

Fig. 41 Abdomen

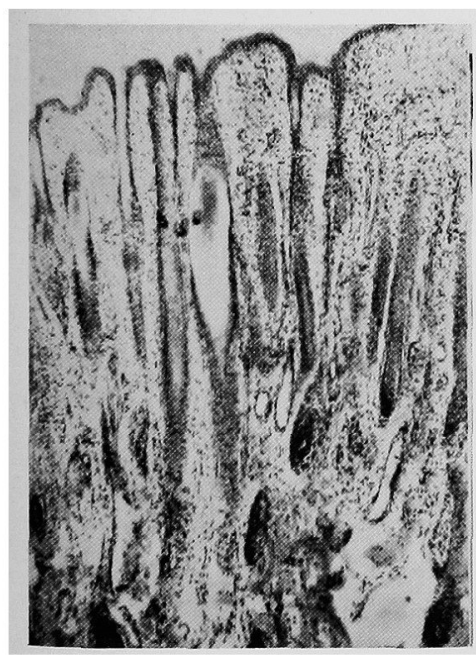

Fig. 42 Hypogastrium

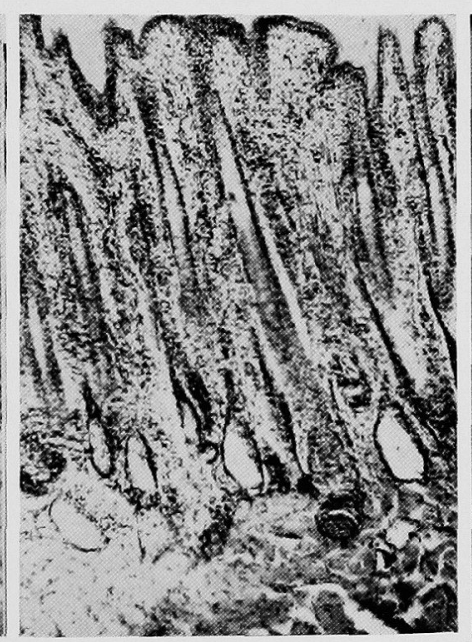

Fig. 43 Back

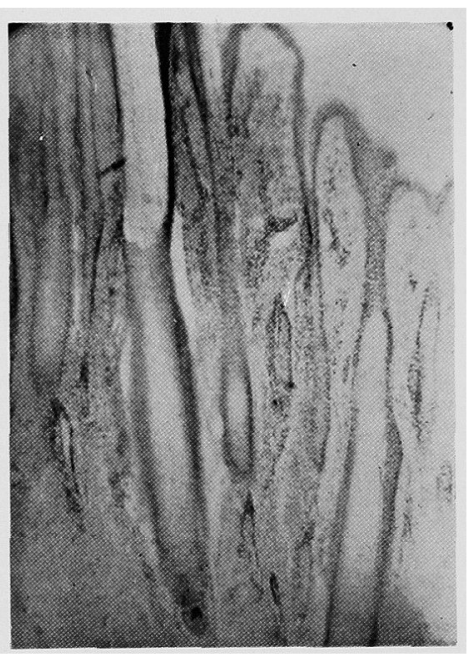

Fig. 44 Sole 